\title{
CONCEPTO Y SISTEMATIZACIÓN DE LA DETENCIÓN ILEGAL EN EL PROCESO PENAL CHILENO
}

["Concept and Systematization of the Illegal Detention in the Chilean Criminal Procedure"]

\author{
Diego Falcone Salas* \\ Pontificia Universidad Católica de Valparaíso, Chile
}

\begin{abstract}
Resumen
Desde el inicio de la vigencia del Código Procesal Penal, en el año 2000, se ha estimado que los jueces de garantía y tribunales de juicio oral en lo penal, son competentes para conocer y resolver acerca de la legalidad de la detención del imputado. Se pretende en este artículo contribuir a precisar en qué consiste la detención ilegal y proponer una manera de sistematizar las hipótesis en que se presenta, con ocasión de un proceso penal.

\section{Palabras clave}

Detención - Medidas cautelares personales - Derecho a la libertad personal - Convención americana de derechos humanos.
\end{abstract}

\begin{abstract}
As from the date the Code of Criminal Procedure became effective in 2000, judges and criminal oral trial courts are competent to hear and rule over the legality of the detention of the accused. This article aims at contributing to the clarification of what is an illegal detention and proposing a way to systematize the hypotheses in which it is presented in a criminal proceeding.

\section{KeYwords}

Detention - Personal precautionary measures - Right to personal freedom American Convention on Human Rights.
\end{abstract}

Recibido el 1 y aceptado el 22 de mayo de 2012

* Profesor de Derecho procesal penal en la Facultad de Derecho de la Pontificia Universidad Católica de Valparaíso. Dirección postal: Facultad de Derecho, Pontificia Universidad Católica de Valparaíso, Avda. Brasil 2950, Valparaíso, Chile. Correo electrónico: diegofalcone@yahoo.com 


\section{INTRODUCCIÓN**}

El sistema procesal penal que entró en vigor el año 2000, fue proyectado para buscar una adecuación de las normas internas, con las que se contenían en ciertos tratados internacionales que Chile había suscrito y ratificado y que, directa o indirectamente, concernían al desenvolvimiento del proceso penal. De esto, quedó constancia en el "Mensaje” del Ejecutivo acompañado al proyecto original, que años más tarde se transformaría en la Ley $N^{\circ} 19.696$, portadora del texto original del Código Procesal Penal (= CPP.)

El centro de la atención en los tiempos de la reforma, estuvo en la adopción del juicio oral. Esto, tanto por el efecto escénico que produce, como por sus virtudes en cuanto vehículo capaz de maximizar ciertas garantías, determinantes a la hora de calificar un proceso como "debido". Pero evidentemente hubo otros cambios tan importantes como el señalado. De enorme trascendencia fue la creación del ministerio público investigador, junto con un órgano jurisdiccional contralor de la adecuada realización de los derechos del imputado y los demás intervinientes: el juez de garantía. El abandono de la figura del juez instructor, sustituido en sus funciones globales por los sujetos procesales indicados, generó la posibilidad de un eficaz control de las actividades investigativa y cautelar.

No es un secreto que los actos de investigación y la imposición de medidas cautelares siempre estuvieron sometidos a exigencias constitucionales y legales, obligatorias para el órgano instructor y para la policía. Tampoco lo es que el control efectivo del cumplimiento de tales exigencias estaba desmejorado, por la reunión en la persona del juez instructor de las facultades de decretar diligencias intrusivas y medidas cautelares, y de verificar la concurrencia de los requisitos establecidos para ellas.

Con la reforma del año 2000 debutó en Chile el control de la legalidad de la detención por el juez de garantía y el tribunal de juicio oral en lo penal. Así, nuestro proceso penal se hizo de una herramienta de verificación efectiva a posteriori, de que la aplicación de la medida cautelar había operado dentro de los márgenes que el derecho permitía. Las características generales de la institución son su ámbito propiamente procesal penal -a diferencia de la acción constitucional de amparo, que pretende el resguardo de la libertad personal frente a cualquier afectación jurídicamente indebida- y el tener como exigencia ineludible que el detenido sea puesto ante el juez.

** Tabla de abreviaturas: CADH. = Convención americana de derechos humanos; CPPen. $=$ Código de Procedimiento Penal de Chile $;$ CP. $=$ Código Penal de Chile CPP . = Código Procesal Penal de Chile; C.Pol. = Constitución Politica de la República de Chile; PIDCP. = Pacto internacional de derechos civiles y politicos. 
A lo largo de estos años, el control de la legalidad de la detención ha provocado desazón en algunos sectores del Estado y de la opinión pública. Esto se ha traducido en varias reformas legales, que se han sucedido desde 2001 hasta la fecha. El objeto de ellas ha sido, en un comienzo, restringir las hipótesis de ilegalidad de la detención y, luego, limitar los efectos de la declaración de ilegalidad. Resulta perturbador pensar que, lo que ha motivado semejante marcha atrás, no ha sido el exceso de celo -el llamado garantismo- del legislador del Código Procesal Penal de 2000, sino el hecho que, por primera vez, la detención haya sido sometida a un escrutinio fino y constante, tendiente a velar por el cumplimiento de su estatuto jurídico, el cual no varió significativamente con el cambio de procedimiento penal.

En el control de la detención el juez debe resolver si esta medida cautelar ha sido legal o ilegal. Por eso consideramos que, en primer lugar, resulta de interés precisar qué debe entenderse por detención ilegal, formulando un concepto para el proceso penal. Como consecuencia de este examen se propondrá, además, una sistematización general y abierta de las hipótesis de detención ilegal. Las pretensiones concluyen aquí. No se trata en este trabajo ni de los efectos de la declaración de ilegalidad, ni de los medios para reclamarla jurisdiccionalmente.

\section{LAS FUENTES FORMALES DE LA DETENCIÓN Y SU PROBLEMÁTICA}

\section{Mención de las fuentes formales que rigen la detención.}

En lo que concierne al ordenamiento jurídico chileno ${ }^{1}$, el derecho fundamental a la libertad personal ${ }^{2}$ se encuentra establecido en diversos textos normativos. Al intérprete y, sobre todo, al titular de dicho derecho -que aquí

${ }^{1}$ Entendemos aquí por "ordenamiento jurídico chileno" el conjunto de normas que rigen actualmente en el territorio del Estado de Chile, siendo aplicables a sus habitantes. Esta noción no sólo abarca las fuentes jurídicas de producción interna, sino también aquellas propias del derecho internacional, que proyectan su fuerza obligatoria en el ámbito interno. Cfr. CORDERo QuinzaCARA, E., Los principios y reglas que estructuran el ordenamiento jurídico chileno, en Ius et Praxis, 15 (2009), pp. 13 y 32.

${ }^{2}$ Preferiremos la denominación "derechos fundamentales" por sobre la de "derechos humanos". Ajusta mejor a las pretensiones de este trabajo, un término lo más desvinculado posible de connotaciones morales y de instrumentalización política. Por otra parte, el esfuerzo se centra aquí en el examen de normas de derecho positivo, así que no resulta de interés, al menos directamente, el acudir a postulados programáticos. Admitimos como válida para este trabajo la noción de derechos fundamentales como derechos humanos positivados aunque en este caso, dada la heterogeneidad de fuentes, no quepa radicarlos exclusivamente en el texto constitucional. Cfr. Aldunate Lizana, E., Derechos fundamentales (Santiago, LegalPublishing, 2008), pp. 45-50; NogueIrA 
es "el detenido"-, resulta razonable concederles que los distintos órganos ${ }^{3}$ productores de tales fuentes formales, han querido garantizar ${ }^{4}$ la existencia y observancia de "un mismo derecho fundamental a la libertad personal"s.

Junto con la formulación del derecho a la libertad personal, las diversas fuentes formales aluden a sus maneras legítimas de afectación. Nos interesa aquí una de ellas: la detención. Libertad personal y detención suelen aparecer en los mismos contextos normativos, vinculadas estrechamente ${ }^{6}$. Ahora bien, las fuentes formales contienen normas que establecen determinadas exigencias, que deben ser observadas al privar de libertad a una persona. Reciben varias denominaciones, entre otras, la de "garantías referentes a la privación de libertad" "Tales garantías varían relativamente en los textos normativos, o bien, son objeto de más o menos detalle en su regulación dependiendo esto, generalmente, de la clase de fuente de que se trate ${ }^{8}$. Hay garantías que

Alcalá, Humberto, Derechos fundamentales y garantias constitucionales (Santiago, Librotecnia, 2008), I, pp. 24, 35-36.

${ }^{3}$ Los sujetos de derecho internacional, incluido el Estado de Chile, que concurren con sus voluntades al tratado; el poder constituyente, que fija el texto constitucional; el legislador.

${ }^{4}$ Considérese aquí la opinión de Aldunate Lizana, E., Derechos, cit. (n. 2), p. 77. $\mathrm{El}$ autor indica que "la garantía es un instrumento al servicio de la concreción fáctica de la promesa normativa. Y que, pudiendo las garantías operar en distintos ámbitos, el primero de ellos es el de la certeza. El grado de mayor vulnerabilidad de un derecho se encuentra en la situación en que su existencia misma es o puede ser discutida. Es por ello que el reconocimiento y la fijación por escrito de un derecho constituyen la expresión más primaria de una garantía, al situarlo al margen de una discusión sobre su existencia".

${ }^{5}$ La pluralidad de fuentes en materia de libertad personal es expresiva del interés que existe por ella, tanto en el ámbito nacional como en el internacional, pero a la vez constituye una dificultad. Semejante dispersión hace dudar acerca de la identidad conceptual en las referencias que hacen unos y otros instrumentos, tanto al derecho fundamental como a sus garantías. Por ello es que la coherencia en la labor interpretativa aparecerá como uno de los problemas iniciales en el presente trabajo.

${ }^{6}$ Esto no ocurre con todas las formas de privación o restricción de la libertad personal. Las penas (privativas o restrictivas de libertad), por ejemplo, no obstante que consisten en hipótesis que quedan incluidas dentro de la formulación general del artículo $19 \mathrm{~N}^{\circ} 7$ letras a) y b) C.Pol., no están tratadas en dicho numeral en forma nominada. Las medidas de seguridad, derechamente, afirmamos que fueron preteridas por la Constitución chilena. El aislamiento, sólo tiene consagración legal en el Código Sanitario (artículos 22 y 55, principalmente).

${ }^{7}$ Silva Bascuñán, Alejandro, Tratado de Derecho constitucional (6a edición, Santiago, Editorial Jurídica de Chile, 2008), XII, pp. 29 ss.

${ }^{8}$ En materia de libertad personal la ley ofrece un pormenor que le es propio y superior, comparativamente, al de la Constitución o los tratados. 
se aplican a cualquier situación de privación de libertad; otras, se aplican a hipótesis específicas, dentro de las que puede estar la detención.

En concreto, las fuentes a que aludimos, que tratan conjuntamente el derecho a la libertad personal, la detención y determinadas garantías referentes a la privación de libertad que se aplican a la detención, son:

i) Los tratados internacionales: De particular relevancia son el Pacto internacional de derechos civiles y politicos (= PIDCP.), promulgado por Decreto No 778 (Diario Oficial de 29 de abril de 1989), especialmente en su artículo 9; y la Convención americana sobre derechos humanos (= CADH.), promulgada por Decreto No 873 (Diario Oficial de 5 de enero de 1991), especialmente en su artículo 7 . Sin embargo, existen otras disposiciones en tales tratados que conciernen a este derecho, como se dirá. También debe considerarse la Convención sobre los derechos del niño, promulgada por Decreto No 830 (Diario Oficial de 27 de septiembre de 1990), particularmente en su artículo 37.

ii) La Constitución Política de la República, fundamentalmente en sus artículos $19 \mathrm{~N}^{\circ} 7$ y 21 .

iii) Las leyes chilenas, en lo fundamental, el Código Procesal Penal, en sus artículos 5, 93, 94, 95, 122 y 125 a 138, principalmente9 ; la Ley № 20.084, que Establece un sistema de responsabilidad penal de los adolescentes por infracciones a la ley penal; y otras leyes especiales, aplicables en el ámbito de la justicia penal reformada (Ley No 20.000, Ley No 18.314, etc.).

Hecha esta enunciación, es preciso analizar, en los apartados siguientes, las consecuencias de la dispersión de fuentes que se abocan al tratamiento de este derecho. Ello, debido a que la posición que se adopte respecto de tal realidad jurídica, traerá consecuencias determinantes en cuanto a la jerarquía de dichas fuentes, su aplicabilidad y, también, su coherencia al interpretarlas.

\section{Jerarquia y aplicabilidad de las fuentes que contienen normas sobre la} detención.

En su configuración tradicional, el ordenamiento jurídico chileno se componía de ciertas fuentes, cuya jerarquía estaba claramente establecida: Constitución Politica, ley y reglamento ${ }^{10}$. Este escenario ha cambiado, adquiriendo mayor complejidad con el tiempo ${ }^{11}$. Para el tema que nos ocupa, es

${ }^{9}$ Hay otras tantas disposiciones. Conviene anotar que el artículo 124 debe coordinarse con el 134, y que el artículo 139 inciso 1 contiene una formulación del derecho a la libertad personal como regla general que, evidentemente, no sólo conoce excepción en virtud de la prisión preventiva.

${ }^{10}$ Véase: Cordero Quinzacara, E., cit. (n. 1), p. 18.

${ }^{11}$ Cordero Quinzacara, E., cit. (n. 1), p. 21. Observa el autor que, "a partir de 1990 comienzan a alumbrar los problemas propios de un sistema normativo en donde 
relevante la progresiva mayor regulación a través de tratados internacionales, de ámbitos que antaño sólo estaban entregados a las normas contenidas en fuentes jurídicas internas.

Destinaremos esta parte del trabajo a intentar precisar cómo interactúan las normas dispuestas en tres fuentes, a saber, la Constitución, los tratados internacionales y la ley

a) La Constitución Politica, en su artículo 6, establece el principio de supremacía $^{12}$. Así, los órganos del Estado deben someterse en sus actos a la Constitución y a las normas dictadas conforme a ella, siendo los preceptos constitucionales obligatorios para los titulares o integrantes de dichos órga$\operatorname{nos}^{13}$. De aquí se desprenden dos ideas principales, que permiten concebir al ordenamiento jurídico chileno como dotado de una estructura, con la propia Constitución a la cabeza: la unidad del ordenamiento jurídico y la existencia de una jerarquía normativa ${ }^{14}$.

Las normas constitucionales gozan de eficacia directa, por lo que son operativas y aplicables en un proceso desde luego, sin necesidad de esperar actividad legislativa posterior que las desarrolle ${ }^{15}$. Por otra parte, la Constitución está por sobre la ley, dado que el legislador, o las personas naturales que, materialmente, desempeñan la función legislativa ${ }^{16}$, se rigen por el artículo 6 C.Pol. ${ }^{17}$. En consecuencia, se habla de la existencia de un "bloque de constitucionalidad" conformado, al menos, por la Constitución Politica y las leyes dictadas conforme a ella (formal y sustancialmente) ${ }^{18}$. La situación

confluyen diversas tradiciones, en donde la disincronía en la integración de sus elementos da pie a una eventual disintonía de los mismos".

${ }^{12}$ Cea Egaña, J. L., Derecho constitucional chileno (2a edición, Santiago, Ediciones Universidad Católica de Chile, 2008), I, p. 239.

${ }^{13}$ Se ha omitido la referencia que hace el texto del artículo a otros destinatarios de las normas constitucionales.

${ }^{14}$ Cfr. Cordero Quinzacara, E., cit. (n. 1), p. 33.

${ }^{15}$ Véase: Bermúdez Soto, Jorge, Derecho administrativo general (Santiago, Legal Publishing, 2010), p. 29; Cea Egaña, J. L., cit. (n. 12), I, p. 244. Sobre su origen, vinculado al Estado Constitucional de Derecho: Aldunate Lizana, E., Derechos, cit. (n. 2), p. 67.

${ }^{16}$ Sobre el alcance del término "órgano del Estado" en la Constitución, consúltese Cea Egaña, J. L., cit. (n. 12), I, p. 242. Cordero Quinzacara, E., cit. (n. 1), p. 37.

${ }^{17}$ Colombo Campbell, Juan, Aspectos constitucionales de la reforma procesal penal, en Revista de Derecho Procesal, 20 (2005), p. 21.

${ }^{18}$ Cea Egaña, J. L., cit. (n. 12), I, p. 243. En sus palabras: "No es la ley, el reglamento o la sentencia, sin más, la manifestación de un órgano estatal que debe ser obedecido, sino que, como lo exige la disposición constitucional analizada, sólo cuando esos actos de los órganos competentes sean dictados con sujeción o de acuerdo con lo previsto en el Código Político. He aquí el llamado Bloque de constitucionalidad [...]”. 
deseable y, seguramente, normal en un proceso penal, consiste en que a su sustanciación y resolución concurran normas constitucionales y legales, estando estas últimas conformes con las primeras. El problema surge, cuando se pretende la inaplicabilidad por inconstitucionalidad de la ley a que se está dando uso en un proceso. En tal caso, dada la estructura dispuesta por la Constitución, en principio podría sostenerse que el único órgano competente para pronunciarse sobre ella es el Tribunal Constitucional. Aunque, al parecer, dicha exclusividad no se corresponde con la mentada eficacia directa, pues lo propio de esta cualidad de las normas constitucionales, es que el juez ordinario también pueda declarar inaplicable la ley por estimarla inconstitucional, en el caso sometido a su conocimiento ${ }^{19}$. Es el llamado "control difuso", que tiene acogida en autorizada doctrin $a^{20}$.

b) Tratado internacional es una convención entre estados, definida usualmente como "un acuerdo internacional celebrado por escrito entre Estados y regido por el derecho internacional, ya conste en un instrumento único o en dos o más instrumentos conexos y cualquiera que sea su denominación particular"21. Interesa en este momento una clasificación propia del derecho internacional, que distingue entre "tratados de derechos humanos" y "otros tratados internacionales" 2 , que denominaremos aquí "comunes". Para examinar la relación que existe entre los tratados internacionales y la

${ }^{19}$ En extenso: Cordero Quinzacara, E., cit. (n. 1), pp. 26-27. Sin embargo, el autor concluye que el juez sólo puede declarar derogada una ley en virtud de la entrada en vigencia de un texto constitucional posterior de sentido diverso pero, en cambio, no puede dejar de aplicar una norma legal posterior a la Constitución y contraria a ella, pues considera que esta labor es de competencia exclusiva del Tribunal Constitucional.

${ }^{20}$ Así Aldunate Lizana, E., Derechos, cit. (n. 2), pp. 203-204. Cea Egaña, J. L., cit. (n. 12), I, p. 249. En esta nota, asumimos como propia la opinión que estima procedente el control difuso, desde nuestra disciplina. La celeridad del procedimiento de detención y su control, la alta probabilidad de término del proceso en la misma audiencia o en un tiempo breve y, además, el hecho que todos los días y horas sean hábiles para las actuaciones judiciales en materia penal, hacen que la existencia de una gestión pendiente como requisito para plantear la cuestión ante el Tribunal Constitucional, dificulte seriamente la iniciativa de su empleo.

${ }^{21}$ Es frecuente en doctrina la adopción de los términos del artículo 2 de la Convención sobre el Derecho de los tratados (Viena, 1969), promulgada por Decreto $\mathrm{N}^{\circ} 381$ (Diario Oficial de 22 de junio de 1981). Véase: Llanos Mansilla, Hugo, Teoría y práctica del Derecho internacional público ( $4^{a}$ edición, Santiago, Editorial Jurídica de Chile, 2009), I, p. 60 ss. Cea Egaña, J. L., cit. (n. 12), I, p. 216. Silva Bascuñán, Alejandro, Tratado de Derecho constitucional (2a edición, Santiago, Editorial Jurídica de Chile, 1997), IV, p. 113. En todo caso, el primero hace notar que dicha definición es restrictiva, ya que un tratado podría no ser escrito y, además, a su celebración podría concurrir con su voluntad otro sujeto de derecho internacional.

${ }^{22}$ Llanos Mansilla, H., cit. (n. 21), I, p. 67. 
ley, expondremos ahora la situación de los tratados comunes, al momento de adquirir vigencia e incorporarse plenamente al ordenamiento jurídico ${ }^{23}$, teniendo en cuenta que su tratamiento por la Constitución y la "Convención de Viena" aludida, es una base general a considerar, también, al tener que examinar la jerarquía y aplicación de los tratados de derechos humanos, a los que nos referiremos después.

Tradicionalmente, se ha entendido que los tratados internacionales comunes poseen el mismo rango, la misma jerarquía, que una ley ${ }^{24}$. Lo propio, entre normas del mismo rango, es que rija el "principio de homogeneidad", consistente en que "las normas que se encuentran en el mismo grado o nivel dentro del ordenamiento tienen el mismo valor y fuerza obligatoria"; lo que trae como consecuencia que, en caso de conflicto entre ellas, ya no quepa "aplicar el criterio de jerarquía para resolver la antinomia, debiendo recurrirse a los criterios de especialidad y temporalidad como mecanismos de solución"25. De aquí fluyen las conocidas reglas de derogación de una ley, ya sea total o parcialmente, en virtud de otra posterior, y de preferencia de aquella que regule un aspecto de modo más particular que otra.

Pero al observar cómo interactúan las leyes con los tratados internacionales comunes, se aprecia que la doctrina, particularmente a partir de la reforma constitucional del año 2005, admite que deben prevalecer las normas del tratado por sobre las de la ley ${ }^{26}$. Esto, ya sea que se estime a aquél como asimilable a la $l \mathrm{y}^{27} \mathrm{o}$, que se le considere una fuente del derecho autónoma. En concreto, se sostiene:

${ }^{23}$ En el entendido que tales reglas son también aplicables a los tratados de derechos humanos, pero que además éstos tendrán, según generalmente se opina, una posición aventajada dentro de la jerarquía normativa.

${ }^{24}$ Cea Egaña, J. L., cit. (n. 12), I, pp. 149 y 217; Guzmán Brito, Alejandro, El Derecho privado constitucional en Chile (Valparaíso, Ediciones Universitarias de Valparaíso, 2001), pp. 118-119. Lo que no significa que, técnicamente, sean leyes. El profesor Guzmán aclara, comentando el texto del artículo $50 \mathrm{~N}^{\circ} 1$ C.Pol. (actual artículo $54 \mathrm{~N}^{\circ}$ 1): "Esto no significa que un tratado sea una ley. Primeramente porque no es tal lo que (la) norma dice, y en seguida, porque eso fuera desconocer la específica entidad de las convenciones internacionales; pero sí significa que el valor o rango normativo interno del tratado es el mismo que el de una ley [...]".

${ }^{25}$ Cordero Quinzacara, E., cit. (n. 1), p. 34.

${ }^{26} \mathrm{Al}$ parecer, jurisprudencialmente se ha seguido la misma tendencia. ZALAQUETT Daher, José - Nash Rojas, Claudio, Proceso penal y derechos humanos, en Revista de Derecho Procesal, 20 (2005), p. 68. Cfr. Aldunate Lizana, E., La posición de los tratados internacionales en el sistema de fuentes del ordenamiento jurídico chileno a la luz del Derecho positivo, en Ius et Praxis, 16 (2010) 2, pp. 205-208.

${ }^{27}$ Una revisión del problema en Aldunate Lizana, E., La posición, cit. (n. 26), pp. $192-197$ y 203. 
i) Que los tratados internacionales tienen la virtud de dejar sin efecto una ley anterior que contenga prescripciones en un sentido diverso ${ }^{28}$.

ii) Que una ley, en cambio, no puede derogar o dejar sin efecto un tratado internacional ${ }^{29}$. Esto, con base en el texto del artículo $54 \mathrm{~N}^{\circ} 1$ C.Pol., que en su inciso 5, expresa: Las disposiciones de un tratado sólo podrán ser derogadas, modificadas o suspendidas en la forma prevista en los propios tratados o de acuerdo a las normas generales de derecho internacional ${ }^{30}$. A esta disposición debe sumarse lo dispuesto en los artículos 26 y 27 de la "Convención de Viena" sobre Derecho de los tratados que, en lo pertinente, indican: "Todo tratado en vigor obliga a las partes y debe ser cumplido por ellas de buena fe" (artículo 26); y "Una parte no podrá invocar las disposiciones de su derecho interno como justificación del incumplimiento de un tratado" (artículo 27) ${ }^{31}$. Interesa recalcar que las disposiciones transcritas no sólo deben considerarse normas internacionales, sino también prescripciones obligatorias en el ámbito inter$\mathrm{no}^{32}$. Desde luego, los tratados en que se contienen tales disposiciones, están vigentes en virtud de un proceso dispuesto por la Constitución, es decir, son normas dictadas conforme a ella, en palabras del artículo 6 C.Pol. Así, obligan a los órganos del Estado, dentro de los que se encuentra el legislador. Todo lo dicho permite concluir que, aunque en doctrina exista una asimilación de los tratados comunes a la ley, en verdad ambas fuentes no concurren en

${ }^{28}$ Cordero Quinzacara, E., cit. (n. 1), p. 46.

${ }^{29}$ Bermúdez Soto, Jorge, cit. (n. 15), p. 37. Para el autor: "Si el tratado internacional es considerado como una ley, una vez promulgado, y como todas las leyes, pasará a formar parte del ordenamiento jurídico y obligará de igual forma. Sin embargo existe una particularidad: la ley no puede modificar un tratado".

${ }^{30}$ Llanos Mansilla, H., cit. (n. 21), I, p. 252. Según el autor, "con esto se consagra la supremacía del tratado sobre la ley puesto que ésta, aunque sea posterior al tratado no lo puede derogar; sólo se puede derogar el tratado conforme al Derecho Internacional”. También fundándose en el artículo $54 \mathrm{~N}^{\circ} 1$ C.Pol., Cordero QUINZACARA, E., cit. (n. 1), p. 46.

${ }^{31}$ Estos artículos de la Convención son citados por algunos autores de derecho constitucional, como argumentos que sirven a la idea de la existencia de un bloque de derechos fundamentales o, para reforzar la argumentación respecto del rango constitucional de los tratados de derechos humanos. Para nuestro trabajo no se requiere ir tan lejos, como se dirá. Cfr. Nogueira Alcalá, H., cit. (n. 2), I, p. 39; Cea Egaña, J. L., cit. (n. 12), I, p. 221.

${ }^{32}$ Cea Egaña, J. L., cit. (n. 12), I, p. 250. Pronunciándose acerca de lo que debe entenderse por ley en el contexto de los artículos 6 y 7 C.Pol.: "Ley es, por ende, un vocablo sinónimo de bloque jurídico en su plenitud. De ese bloque es parte o componente relevante el ordenamiento jurídico contenido en los tratados internacionales, ratificados por Chile y con vigor actual en nuestro país". Cfr. Aldunate Lizana, E., La posición, cit. (n. 26), p. 190. 
forma homogénea a la configuración del ordenamiento jurídico, situándose los tratados internacionales en una jerarquía superior ${ }^{33}$.

Los tratados comunes también plantean problemas en caso de conflicto con la Constitución, asunto que no examinaremos, por ser ajeno a los objetivos de este trabajo ${ }^{34}$. En todo caso, como los tratados comunes generan derechos y obligaciones entre estados, en el evento de su incumplimiento se entra de lleno en el ámbito de la responsabilidad internaciona ${ }^{35}$.

c) Los tratados internacionales de derechos humanos tienen una naturaleza diversa que los comunes. En ellos los estados concurren con su voluntad para obligarse a un fin común, que se proyecta hacia los habitantes individualmente considerados, en el sentido de tener éstos, en virtud de tal instrumento, un derecho fundamental que hacer valer ante el Estado ${ }^{36}$.

${ }^{33}$ Cfr. Cordero Quinzacara, E., cit. (n. 1), p. 46. Examinando el tema como un caso particular de integración de fuentes al ordenamiento jurídico, concluye que, en virtud del artículo $54 \mathrm{n}^{\circ} 1$, se está haciendo aplicación del "principio del procedimiento", y no del de jerarquía. En todo caso, lo relevante para este trabajo es que la ley no puede disponer en sentido diverso, sobre materias ya reguladas en virtud de un tratado.

${ }^{34}$ Cfr. Silva Bascuñán, A., cit. (n. 21), IV, p. 121. Explicando la posición de los tratados de derechos humanos dentro del ordenamiento, apela también al régimen común, señalando: "En tanto un tratado se halle vigente, el Estado no puede actuar con prescindencia o en contra de los compromisos contraídos conforme a él, ni está facultado para derogar o modificar regla alguna de su ordenamiento interno sin previo acuerdo con el Estado, los Estados, las organizaciones o sociedad internacional con quienes se haya comprometido. No pueden así dictarse normas constitucionales, legales o administrativas que debiliten, perturben o impidan los efectos o el alcance de los compromisos contraídos. Así la 'Convención de Viena' dispone: "Todo tratado en vigor obliga a las partes y debe ser cumplido por ellas de buena fe (artículo 26)”.

${ }^{35}$ Llanos Mansilla, Huho, Teoría y práctica del Derecho internacional público (3a edición, Santiago, Editorial Jurídica de Chile, 2007), II, p. 723. Indica: "El fundamento de la responsabilidad internacional es la violación, por parte del Estado, de una obligación internacional, como consecuencia de la cual se debe una reparación al Estado perjudicado por el acto ilícito".

${ }^{36}$ Medina Quiroga, Cecilia, La Convención americana: Teoria y jurisprudencia (Santiago, Centro de Derechos Humanos. Facultad de Derecho Universidad de Chile, 2003), p. 8. "Los tratados de derechos humanos, a diferencia de otros tratados internacionales, confieren derechos a los individuos frente al Estado, el que, a su vez, tiene obligaciones para con ellos”. CEA Egaña, J. L., cit. (n. 12), I, pp. 224-225, con jurisprudencia nacional en el mismo sentido. CANÇADo TRINIDADE, Antonio, El Derecho internacional de los derechos humanos en el siglo XXI (2a edición, Santiago, Editorial Jurídica de Chile, 2006), p. 24. "Los tratados de derechos humanos son claramente distintos de los tratados de tipo clásico, que establecen o reglamentan derechos subjetivos o concesiones o ventajas recíprocas para las Partes Contratantes. Los tratados de 
La ley no puede contravenir lo dispuesto en tratados internacionales de derechos humanos. En primer lugar, porque éstos se sujetan al régimen general de los tratados comunes, ya examinado. Luego, porque su estatuto constitucional está reforzado en virtud del artículo 5 inciso $2^{\circ} \mathrm{C}$.Pol., que expresa: "El ejercicio de la soberanía reconoce como limitación el respeto a los derechos esenciales que emanan de la naturaleza humana. Es deber de los órganos del Estado respetar y promover tales derechos, garantizados por esta Constitución, asi como por los tratados internacionales ratificados por Chile y que se encuentren vigentes". Esto, en lo que dice relación con la sujeción de los órganos del Estado -incluidos aquellos que ejercen la función legislativa-, al deber de respeto y promoción de los derechos fundamentales dispuestos en ellos. Sobre el punto, existen disposiciones en los tratados que conciernen a este trabajo, que se plantean en términos análogos y que, según lo dicho, obligan también en el ámbito interno, sin que quepa modificación por la vía legal a su respecto ${ }^{37}$.

Desde otro ángulo, algunos sostienen por principio que las normas de derechos humanos, contenidas en tratados, son autoejecutables, es decir, que gozan, al igual que la Constitución, de eficacia directa. Dada esta virtud, no requerirían de legislación que las haga operativas y, además, si las normas de derecho interno estuviesen en contraposición a ellas, quedarían derogadas ${ }^{38}$. El hecho es que, más allá de las formulaciones doctrinarias generales, existen tratados internacionales de derechos humanos que, por los propios términos en que se plantean, son autoejecutables. Es el caso de la Convención americana de derechos humanos, dada la redacción de su artículo $1^{39}$.

De todo lo dicho se desprenden dos conclusiones que nos conducen al mismo punto. En primer lugar, con el actual texto del artículo $54 \mathrm{~N}^{\circ} 1$ inciso

derechos humanos, en contrapartida, prescriben obligaciones de carácter esencialmente objetivo, que deben ser garantizadas o implementadas colectivamente, y enfatizan el predominio de consideraciones de interés general u 'ordre public' que trascienden los intereses individuales de las partes contratantes”. Llanos MANsilla, H., cit. (n. 21), I, pp. 67 y 378. Cita el autor las definiciones de la Corte Interamericana de Derechos Humanos y del profesor Cançado Trinidade. Véase: Aldunate Lizana, E., Derechos, cit. (n. 2), pp. 51-57 y 126, especialmente. Cfr. Silva Bascuñán, Alejandro, cit. (n. 21), IV, pp. 114-115, quien mantiene la noción de derecho subjetivo en favor de los individuos.

${ }^{37}$ Nos referimos especialmente al artículo $1 \mathrm{CADH}$. que, en lo pertinente, indica: "Los estados partes en esta convención se comprometen a respetar los derechos y libertades reconocidos en ella y a garantizar su libre y pleno ejercicio a toda persona que esté sujeta a su jurisdicción [...]”. Véase también el artículo 2.1 PIDCP.

${ }^{38}$ Zalaquett Daher, J. - Nash Rojas, C., Proceso, cit. (n. 26), p. 70.

${ }^{39}$ Llanos Mansilla, H., cit. (n.21), I, p. 65; Medina Quiroga, C., cit. (n. 36), pp. 16-26. 
$5^{\circ}$ C.Pol., ha quedado claro que la única manera en que un tratado puede dejar de estar vigente, es de acuerdo con los mecanismos dispuestos por el derecho internacional, no siendo posible sostener que ello también podría ocurrir mediante la dictación de una ley que lo derogara, expresa o tácitamente ${ }^{40}$. En segundo término, sin perjuicio de la posición que se adopte, en cuanto a la jerarquía de los tratados internacionales de derechos humanos frente a la Constitución, ha quedado demostrado que el legislador se encuentra obligado, por normas que tienen eficacia en el ámbito interno, a respetar y promover los derechos fundamentales contenidos en dichos tratados. Esto, por expresa disposición de una norma de rango constitucional, cual es el artículo 5 inciso $2^{\circ}$ C.Pol. ${ }^{41}$. En consecuencia, aquellas disposiciones legales que contraríen tratados internacionales de derechos humanos, quedan en situación de ser consideradas inaplicables al caso particular ${ }^{42}$ e, incluso, de estimarse inconstitucionales y ser derogadas, de conformidad con los artículos 93 números 6 y 7, y 94 C.Pol. Esta contrariedad, fundamento de la inconstitucionalidad, puede consistir ya en que la ley pretende derogar, expresa o tácitamente, todo o parte de sus disposiciones (inconstitucionalidad relacionada con el artículo $54 \mathrm{~N}^{\circ} 1$ C.Pol.) o, en que la ley contiene prescripciones normativas que desatienden el respeto y promoción de los derechos fundamentales garantizados por tales tratados (inconstitucionalidad relacionada con el artículo 5 inciso $2^{\circ}$ C.Pol.).

Lo anterior no excluye que se persiga la responsabilidad internacional del Estado en caso de incumplimiento de un tratado internacional de derechos humanos ${ }^{43}$. Dicha responsabilidad opera de modo adicional, ante una jurisdicción diferente, y en ningún caso es argumento para sostener que la infracción constitucional no debiera ser resuelta por vía de inaplicabilidad o derogación, en su caso ${ }^{44}$.

${ }^{40}$ Esto, a propósito de lo dispuesto al final del artículo 5 inciso $2^{\circ}$ C.Pol.: “[... y que se encuentren vigentes".

${ }^{41}$ Véase: Aldunate Lizana, E., Derechos, cit. (n. 2), p. 343.

${ }^{42}$ Por el Tribunal Constitucional o, incluso, por el juez o tribunal con competencia penal, si se estima procedente el control difuso a que hemos hecho referencia.

${ }^{43}$ Medina Quiroga, C., cit. (n.36), pp. 28 ss.

${ }^{44}$ Cfr. Medina Quiroga, C., cit. (n. 36), p. 18. "El que los individuos puedan usar y gozar sus derechos humanos es una responsabilidad primaria de los Estados, que son los que están en mejor posición para asegurarles que ello pueda suceder de manera cotidiana e inmediata; la supervisión internacional siempre es tardía y generalmente ex post. La obligación existe aun cuando pueda concluirse que, en determinados ordenamientos jurídicos, la vigencia de los tratados produce efectos de derogación respecto de normas internas contrarias a las normas internacionales". Además, debe considerarse que, la propia resistencia a declarar la inaplicabilidad puede ser fuente de responsabilidad internacional, ya no por actuar del legislador, sino del órgano respectivo. 
En su relación con la Constitución, hablar de estos tratados en Chile, significa ingresar en la polémica existente acerca de cómo debe interpretarse el artículo 5 inciso $2^{\circ}$ C.Pol.. Al respecto se ha escrito mucho ${ }^{45}$, y en sentidos diametralmente opuestos, señalándose que tales tratados tienen jerarquía supraconstitucional, constitucional -ya los tratados o los derechos contenidos en ellos-, o infraconstitucional.

Frente a este escenario, cabe hacer una crítica severa al propio texto de la Constitución. El artículo 5 inciso $2^{\circ} \mathrm{C}$.Pol. era la norma destinada a articular las fuentes del derecho de producción interna, con aquellas provenientes de la celebración de tratados que contuviesen derechos fundamentales, de modo que se pudiera hablar, en propiedad, de la configuración de un ordenamiento jurídico chileno, en que rigiesen todas estas disposiciones de manera coherente ${ }^{46}$. Esta aspiración es particularmente importante, en el ámbito de aquellos derechos que se conocen como garantías del imputado en el proceso penal ${ }^{47}$, dado que la Constitución no es prolífica en su establecimiento $^{48}$. Pero en este trabajo debemos partir de la base que, respecto del artículo 5 inciso $2^{\circ} \mathrm{C}$.Pol., no cabe cifrar esperanzas al respecto. Ello, porque existen antecedentes de que, en su redacción, se buscó una formulación poco clara, que se acomodara mejor a la situación política del momento, con la intención de trasladar el problema de la fijación de su sentido y alcance, a

${ }^{45}$ Para una exposición ordenada de las posiciones que se han conformado: Guzmán Brito, A., cit. (n. 24), pp. 103 ss.; Aldunate Lizana, E., Derechos, cit. (n. 2), pp. 338 ss.

${ }^{46}$ Cfr. Cordero Quinzacara, E., cit. (n. 1), p. 13. Uno de los elementos esenciales para que exista un ordenamiento jurídico es la coherencia del conjunto de normas jurídicas que lo compone. Para examinar la posición que aprecia en el caso chileno la existencia de un bloque de derechos fundamentales, Nogueira Alcalá, H., Derechos, cit. (n. 2), I, PP. 36 ss. Cfr. Aldunate Lizana, E., Derechos, cit. (n. 2), pp. 129-131.

${ }^{47}$ Nos referimos tanto a las "garantías judiciales", como a toda otra que tenga incidencia en el estatuto del imputado.

${ }^{48}$ Véase: Tavolari Oliveros, Raúl, Las medidas cautelares, en Revista de Derecho Procesal, 20 (2005), p. 283; CARocCA PÉREZ, Alex, Las garantias constitucionales en el nuevo proceso penal, en Carocca Pérez, Alex - Duce Julio, Mauricio - Riego Ramírez, Cristián - Baytelman Aronowsky, Andrés - Vargas Vivanco, Juan Enrique (editores), Nuevo proceso penal (Santiago, ConoSur, 2000), p. 43; Risso Ferrand, Martín, Algunas garantías básicas de los derechos humanos (Montevideo, Fundación de Cultura Universitaria, 2008), p. 22. Respecto de las disposiciones constitucionales que conceden rango constitucional o preeminencia sobre el derecho interno, a los derechos humanos contenidos en tratados, señala: "Este tipo de soluciones modernas resultan por demás interesantes a los efectos de suplir olvidos o completar la regulación constitucional de los derechos humanos". 
la jurisprudencia ${ }^{49}$. El resultado está a la vista ${ }^{50} \mathrm{y}$, por este motivo, sólo cabe señalar que parece inexcusable la mantención del texto del artículo 5 inciso $2^{\circ}$ C.Pol. por más de veinte años ${ }^{51}$.

Desde nuestra perspectiva, más que especular acerca del posible rango constitucional o supraconstitucional de los tratados internacionales de derechos humanos, resulta prioritario dejar clara la sumisión que se impone al legislador y a los demás órganos del Estado en su actuar, en materia de tales derechos. Esto, asumiendo que las probabilidades de contravención al conjunto de derechos fundamentales, contenidos en la Constitución y los tratados, por estas mismas fuentes, son menores que las que exhiben el legislador y los demás órganos estatales ${ }^{52}$. Por lo tanto, para desarrollar nuestras ideas aquí, nos situaremos en el escenario más moderado respecto del problema que, según se ha venido explicando, consiste en que a la cabeza del ordenamiento jurídico chileno está la Constitución y, supeditados a ella se encuentran, en primer lugar, los tratados internacionales de derechos humanos y, luego, las leyes.

\section{La necesidad de coherencia en la interpretación.}

Partiendo de la base que las fuentes de la detención son constitucionales, de derecho internacional y, también, legales, se hace necesario buscar una manera coherente de interpretar todas ellas. Se observa en este nivel un problema similar al anteriormente revisado, esto es, de qué rama del derecho obtener las directrices de interpretación; del derecho constitucional, el derecho internacional de los derechos humanos o el derecho común ${ }^{53}$.

Si hemos situado a la Constitución en la cima de las fuentes formales del derecho, optaremos por considerar, también, el principio de interpretación

${ }^{49}$ Cfr. Guzmán BRito, A., cit. (n. 24), pp. 105-106. Recopila las opiniones vertidas en los trabajos de Francisco Cumplido.

${ }^{50}$ Sobre lo dispar y, en consecuencia, impredecible, de la jurisprudencia nacional, gravemente perturbada, pensamos, por la ambigüedad de la redacción del texto constitucional en este punto, obsérvese el análisis de CEA EGAÑA, J. L., cit. (n. 12), I, pp. 222-237.

${ }^{51}$ Para establecer una comparación con textos constitucionales extranjeros, Nogueira Alcalá, H., (n. 2), I, pp. 28-29. Risso Ferrand, M., cit. (n. 48), pp. 21-23. Ambos examinan el contexto latinoamericano.

${ }^{52} \mathrm{El}$ conflicto que crea el texto del artículo 5 inciso $2^{\circ} \mathrm{C}$.Pol. es un problema menor en un sentido probabilístico, puesto que sólo se activará en el caso que exista pugna entre la Constitución y los tratados internacionales de derechos humanos.

${ }^{53}$ Cfr. Nogueira Alcalá, Humberto, (n. 2), I, pp. 45-47, 81-89, 223 ss.; Medina Quiroga, C., cit. (n. 36), pp. 4-11; Llanos Mansilla, H., cit. (n. 21), I, pp. 192-199, 378-380; Cea Egaña, J. L., cit. (n. 12), I, p. 153-156; Aldunate Lizana, E., Derechos, cit. (n. 2), pp. 123-131. 
conforme a la Constitución como punto de arranque ${ }^{54}$. De acuerdo con éste, y específicamente en materia de derechos fundamentales, debe fijarse el sentido de las restantes fuentes formales teniendo siempre en cuenta la preceptiva constitucional. Esto, como una piedra angular que constituye a toda interpretación en una interesada en el ineludible deber de respeto y promoción que ordena el artículo 5 inciso $2^{\circ}$ C.Pol..$^{55}$. Teniendo en cuenta esta disposición se deben observar, también, las reglas interpretativas de fuente internacional, que sean aplicables en el ámbito interno; tanto las generales, como las específicas de algún tratado de derechos humanos ${ }^{56}$, advirtiendo que estas últimas, en síntesis, persiguen la finalidad de nunca provocar un desmedro en materia de derechos fundamentales.

Se discute si la jurisprudencia de órganos internacionales, sobre la aplicación de tratados de derechos humanos, es vinculante en nuestro sistema jurídico ${ }^{57}$. Aunque se estime que no lo sea, para un juez que ejerce su jurisdicción en el ámbito interno, y que debe resolver ateniéndose a las normas del mismo tratado, no parece razonable que tales fallos sean pasados por alto y, al contrario, constituyen un rico material para apoyar su razonamiento.

Al momento de interpretar la ley, deben además ser tomados en cuenta, necesariamente, los medios de interpretación dispuestos por los artículos 19 a 24 CC..$^{58}$. Conforme con todo lo dicho, será labor del intérprete discernir si, en el caso concreto, corresponde dar primacía a éstos, y en el orden que se han establecido o, por el contrario, la Constitución impone una asignación de sentido ante todo teleológica. Ahora bien, en materia procesal penal

${ }^{54}$ Cordero Quinzacara, E., cit. (n. 1), p. 31. Cita jurisprudencia Cea Egaña, J. L., cit. (n. 12), I, p. 227.

${ }^{55}$ Aldunate Lizana, E., Derechos, cit. (n. 2), p. 202. "Fuera de la jurisdicción constitucional, el principio de interpretación conforme a la Constitución no es otra cosa sino un aspecto del deber de integración de las fuentes del ordenamiento jurídico en vistas a determinar la norma rectora de un caso; para ello, el juez debe tener presente su vinculación directa a la Constitución (artículo $6^{\circ}$ i. I, II) e incorporar en el proceso de interpretación de la ley los elementos dados por la Carta Fundamental. En el caso de los derechos fundamentales, y aparte de las disposiciones del artículo 19, por mandato constitucional del artículo $5^{\circ}$ i. II, este deber de integración se extiende a aquellas disposiciones de los tratados internacionales que pueden estimarse formando parte de los derechos esenciales que emanan de la naturaleza humana. E involucra un principio de interpretación interesada en cumplimiento del deber de promoción, contemplado en el mismo precepto".

${ }^{56}$ Véase el artículo 31 de la Convención sobre Derecho de los Tratados y el artículo $29 \mathrm{CADH}$.

${ }^{57}$ Cfr. Medina Quiroga, C., cit. (n. 36), p. 5; Aldunate Lizana, E., Derechos, cit. (n. 2), p. 130.

${ }^{58}$ Respecto de la aplicación de las disposiciones del Código Civil para la interpretación de los tratados, Aldunate Lizana, E., La posición, cit. (n. 26), p. 204. 
debe atenderse al artículo 5 inciso $2^{\circ} \mathrm{CPP}$., que establece: "Las disposiciones de este Código que autorizan la restricción de la libertad o de otros derechos del imputado o del ejercicio de alguna de sus facultades serán interpretadas restrictivamente y no sepodrán aplicar por analogia", prescripción que, según se ha señalado, se funda en los derechos a la presunción de inocencia y de defensa ${ }^{59}$, constituyendo un principio interpretativo que prevalece sobre lo dispuesto en el artículo 23 CC., fijando un límite ineludible que procura la realización efectiva de los derechos del imputado en el proceso penal ${ }^{60}$.

\section{UN CONCEPTO DE DETENCIÓN}

\section{La detención tomada en sentido amplio ${ }^{61}$.}

En un sentido amplio, con el término "detención", se suele significar la privación de libertad que sufre una persona, ya en el contexto de un proceso penal o fuera de éste, por diversos motivos. El fundamento de tal concepción radica, esencialmente, en permitir el disfrute del estatuto de derechos del detenido, por parte de toda persona privada de libertad. Para aquélla, el acento se debe poner en la situación de hecho de privación de libertad, siendo irrelevantes las denominaciones puntuales con que las nombre el ordenamiento jurídico ${ }^{62}$.

${ }^{59}$ MaIer, Julio, Derecho procesal penal (2a edición, Buenos Aires, Editores del Puerto, 1996), I, pp. 229, 234 y 235.

${ }^{60}$ Interesa destacar cómo, a través de la disposición legal, se plasma una regla interpretativa puesta en tela de juicio en el derecho penal sustantivo y que, en dicho ámbito, se identifica con el principio "in dubio pro reo". Véase: Novoa Monreal, E., Curso de Derecho penal chileno (Santiago, Editorial Jurídica de Chile, 1960), I, p. 140. Estimamos que el artículo 5 inciso $2^{\circ} \mathrm{CPP}$. es expresión de aquel principio en el proceso penal, a pesar que en esta materia lo habitual sea que se le vincule, específicamente, con la convicción de culpabilidad del acusado, de conformidad con la prueba rendida en el juicio. Politoff Lifschitz, Sergio - Matus Acuña, Jean Pierre - Ramírez Guzmán, María Cecilia, Lecciones de Derecho penal chileno. Parte General (Santiago, Editorial Jurídica de Chile, 2004), p. 114. Cfr. Roxin, Claus, Derecho procesal penal (Buenos Aires, Editores del Puerto, 2003), p. 111; MAIER, Julio, cit. (n. 59), pp. 494-505.

${ }^{61}$ Para referencias acerca del tema en España, véase: GonzÁlez Ayala, María Dolores, Las garantías constitucionales de la detención (Madrid, Centro de Estudios Políticos y Constitucionales, 1999), pp. 50-62.

${ }^{62}$ Gimeno Sendra, Vicente, Derecho Procesal Penal (2a edición, Madrid, COLEX, 2004), pp. 508 y 540. Llama detenciones “especiales" o "atípicas" a las que no se encuentran reguladas en la Ley de Enjuiciamiento Criminal española, ni participan con plenitud de la naturaleza de las medidas cautelares. Les confiere relevancia al momento de determinar la procedencia del "Habeas Corpus". Gimeno Sendra, Vicente - Moreno Catena, Víctor - Cortés Domínguez, Valentín, Derecho procesal penal ( $3^{\mathrm{a}}$ edición, Madrid, COLEX, 1999), p. 485; Horvitz, María Inés - López, Julián, De- 
Dentro del contexto del proceso penal chileno, bajo el alero de la detención así entendida, podrían quedar captadas figuras como la conducción a la unidad policial más cercana para fines de identificación (artículo $85 \mathrm{CPP}$. ${ }^{63}$, la conducción al recinto policial para efectuar una citación (artículo 134 inciso $3^{\circ} \mathrm{CPP}$.), el arresto de testigos legalmente citados al juicio (artículos 299 y 33 CPP.) o la conducción de personas mediante la fuerza pública ante el fiscal (artículos 23 y 190 inciso $2^{\circ} \mathrm{CPP}$.).

Fuera del proceso penal, podría pensarse en casos adicionales. Por ejemplo, la conducción a un cuartel policial, dispuesta en los artículos 27 y 28 , relacionados con el artículo 53 de la Ley No 19.925, de alcoholes.

En definitiva, la idea es hacer extensivo el concepto de detención a toda gama de privaciones de libertad, ya sea que éstas tengan nombre y regulación legal ${ }^{64} \mathrm{o}$, por el contrario, sean inespecíficas ${ }^{65}$. Lo fundamental aquí es posibilitar el control, tanto de la existencia de fundamento jurídico para llevarlas a cabo, como de la observancia de los procedimientos correspondientes.

Esta manera de concebir la detención es compatible, también, con las necesidades que debe cubrir el sistema de derecho internacional de los derechos humanos. En virtud de las disposiciones de los instrumentos internacionales respectivos, en materia de libertad personal, generalmente los organismos que les están vinculados, han dirigido su atención a las lesiones de ella más irregulares o distantes de la juridicidad ${ }^{66}$, siendo irrelevante que la privación del derecho se produzca en un proceso penal o en otro contexto, y si quien la practica es un policía u otro funcionario, o un particular ${ }^{67}$. Normalmente, sí,

recho procesal penal chileno (Santiago de Chile, Editorial Jurídica de Chile, 2002), I, p. 362; Arias Vicencio, Cristián, El control jurisdiccional de la detención, en Revista de Estudios de la Justicia, 6 (2005), p. 230. Cfr. Nogueira Alcalá, Humberto, Derechos fundamentales y garantías constitucionales (Santiago, Librotecnia, 2008), II, p. 411.

${ }^{63}$ Horvitz, M. I - López, J., cit. (n. 62), I, p. 380.

${ }^{64}$ Por ejemplo, el arresto del alimentante dispuesto en el artículo 14 de la Ley $\mathrm{N}^{\circ}$ 14908 .

${ }^{65}$ Como las "invitaciones" que podrían realizar funcionarios policiales al cuartel, con finalidad de investigar, a sabiendas que el ciudadano es ignorante de la posibilidad de expresar su negativa, o se siente de todas formas coaccionado.

${ }^{66}$ Bovino, Alberto, Justicia penal y derechos humanos (Buenos Aires, Editores del Puerto, 2004), p. 56. En sus palabras, "durante los primeros años de trabajo de los órganos del sistema (interamericano), la atención de los diversos operadores jurídicos se concentraba en contextos de groseras violaciones sistemáticas a los derechos humanos".

${ }^{67}$ Medina, C., cit. (n. 36), pp. 212 - 214. Señala como ejemplo "el encierro de las mujeres dentro de su hogar, recinto del cual no pueden salir a menos que se los permita el marido, autorizado por el derecho consuetudinario en ciertos países musulmanes". 
los casos que han sido conocidos por dichos organismos tienen como sujetos activos de la supuesta afectación ilícita a agentes del Estado ${ }^{68}$.

Se advierte que, para esta concepción, no es determinante que la privación de libertad se vincule con la consecución de algún fin del procedimiento penal, ni que ella recaiga en la persona del imputado ni, tampoco, que exista necesariamente un proceso penal.

El concepto amplio de detención se ve acotado, en primer lugar, mediante la exclusión de tal ámbito, de la prisión preventiva ${ }^{69}$. Tradicionalmente, esta medida cautelar ha tenido una denominación específica, que se corresponde con un perfil conceptual bien definido y un tratamiento normativo propio ${ }^{70}$. Actualmente, en el contexto del ordenamiento jurídico chileno habría que situar, junto a ella, la internación provisional del enajenado mental (artículo 464 CPP.) y la internación provisoria del menor (artículo 32 Ley No 20084). También quedarían excluidas del ámbito de la detención en sentido amplio, las demás medidas cautelares personales que se sujeten a requisitos análogos a la prisión preventiva y puedan considerarse privaciones de libertad; así el llamado "arresto domiciliario" del artículo 155 letra a) CPP., y la medida dispuesta en el artículo 155 b) CPP., en tanto esta última se emplee como mecanismo de privación de libertad durante cierto tiempo -por ejemplo, si la sujeción a vigilancia es, en los hechos, un internamiento en un establecimiento de salud-.

Se excluye asimismo de esta concepción, el cumplimiento de la pena privativa de libertad ${ }^{71}$, que es consecuencia de la responsabilidad penal declarada mediante una sentencia condenatoria firme ${ }^{72}$.

\section{La detención para efectos de este trabajo.}

En los términos anteriores el sujeto que, con motivo de un control de identidad, es privado de libertad y conducido a la unidad policial, para ser liberado unas horas después, ha sufrido una detención. Y el que es llevado por agentes de seguridad o inteligencia estatales, para nunca más ser visto,

${ }^{68}$ Como referencia, pueden consultarse los casos citados por Medina, C., cit. (n. 36), p. 218 ss.; Bovino, A., cit. (n. 66), p. 57. "Finalmente, como veremos al analizar la jurisprudencia de la Corte Interamericana de Derechos Humanos en la materia [...], este órgano se ha 'especializado' en detenciones manifiestamente ilegales [...] vinculadas a secuestros, ejecuciones extrajudiciales y desapariciones forzadas".

${ }^{69}$ Gimeno Sendra, V., cit. (n. 62), p. 508; Horvitz, M. I. - López, J., cit. (n. 62), I, p. 362.

${ }^{70} \mathrm{En}$ el artículo $19 \mathrm{~N}^{\circ} 7 \mathrm{C}$.Pol. la prisión preventiva claramente aparece diferenciada de las otras privaciones de libertad.

${ }^{71}$ Horvitz, M. I. - López, J., cit. (n. 62), I, p. 362.

${ }^{72}$ Véanse los artículos 4 CPP. y 79 CP. 
también ${ }^{73}$. Pero estos casos probablemente no serán objeto de un oportuno control jurisdiccional.

Por otra parte, antes de conceder demasiada holgura al término "detención", sería importante verificar si en Chile resulta ello justificado o si, por el contrario, existe ya un régimen general de protección del privado de libertad, que resulta satisfactorio ${ }^{74}$. Además, cabría examinar si, normativamente, es posible referirse a cualquier privación de libertad como "detención". Respecto de esto último interesa tener presente que, desde la perspectiva constitucional, los autores nacionales estiman que la detención en nuestra Carta Fundamental se corresponde con el estado de privación de libertad, por breve tiempo, de una persona imputada en un proceso penal ${ }^{75}$. De hecho, consta que estos fueron los elementos que se tomaron en cuenta para diferenciar la "detención" del "arresto", al discutirse la redacción del artículo $19 \mathrm{~N}^{\circ} 7$ b) C.Pol. ${ }^{76}$.

Para nuestro trabajo interesa, fundamentalmente, la detención entendida como aquella privación de libertad del imputado, que es denominada como tal y regulada dentro de las medidas cautelares personales, por el Código Procesal Penal y que, normalmente, será objeto de control judicial en virtud del artículo 132 CPP.

Esta definición funcional que ofrecemos, es compatible tanto con el sentido constitucional de la institución, como con el asignado en el ámbito del derecho internacional ${ }^{77}$.

${ }^{73}$ La llamada "desaparición forzada de personas", constante preocupación en el ámbito del Derecho internacional. Cfr. Medina Quiroga, C., cit. (n. 36), pp. 123 ss.

${ }^{74} \mathrm{Al}$ menos, los artículos $19 \mathrm{~N}^{\circ} 7$ y 21 C.Pol., y los artículos 94 y 95 CPP., claramente abarcan también otras hipótesis de privación de libertad, y no sólo la detención. Por otra parte, existen ciertos derechos propios del detenido que son irrealizables con motivo de individuos privados de libertad por otra causa y, a la vez, derechos particulares de éstos que serían inaplicables a un detenido. Véase la parte final del artículo 86 CPP. Considérese lo inoficioso que sería proclamar que el artículo 132 se extiende al solo control de identidad.

${ }^{75}$ Evans de la CuAdra, Enrique, Los derechos constitucionales (3a edición, Editorial Jurídica de Chile, Santiago, 1999), II, p. 181; Verdugo Marinkovic, Mario - Pfeffer Urguiaga, Emilio - Nogueira Alcalá, Humberto, Derecho constitucional ( $2^{a}$ edición, Editorial Jurídica de Chile, Santiago, 2005), I, p. 238. Cfr. Nogueira Alcalá, H., cit. (n. 2), II, p. 411.

${ }^{76}$ Silva Bascuñán, A., cit. (n. 7), XII, pp. 29-32. Próximo a esta idea de detención se encuentra MARÍn GonzÁlez, Juan Carlos, Las medidas cautelares personales en el nuevo Código Procesal Penal chileno, en Revista de Estudios de la Justicia, 1 (2002), p. 23.

${ }^{77}$ Medina Quiroga, C., cit. (n. 36), p. 223. “[...] se dijo que el artículo 7 de la Convención protege a los individuos de toda privación de libertad que sea ilegal o arbitraria, pero que, sin perjuicio de ello, esta disposición reglamenta con detalle las 
Una mención especial requiere la "aprehensión" del imputado libre, en virtud de orden dictada por el juez de garantía. En nuestra opinión, se trata de una detención cautelar ${ }^{78}$, por orden judicial, y debe someterse a control a posteriori por el juez de garantía, según el artículo $132 \mathrm{CPP} .{ }^{79}$. De no entenderse así, se produciría la indefensión del sujeto respecto del procedimiento de detención, pese a que aún conserva su calidad de imputado y todos los derechos propios de su estatuto, que sean compatibles con su carácter de condenado. De conformidad con el artículo 468 inciso $2^{\circ} \mathrm{CPP}$., el orden consecutivo de los actos de ejecución es, en primer lugar, la dictación de la orden de aprehensión y su verificación y, luego, la remisión de copia de la sentencia firme al establecimiento penitenciario y la dictación de la orden de ingreso del condenado a éste. Es decir, no se trata de conducir directamente al imputado condenado desde la calle hasta la cárcel.

$\mathrm{Al}$ avanzar en el examen acerca de cuándo existe detención ilegal, interesará tener presente que la detención está constituida por el acto mismo de privar de libertad a una persona -su "inmovilización" ${ }^{80}$-, pero también es comprensiva del período que comienza en ese instante y que se extiende hasta la cesación de la medida ${ }^{81}$. En consecuencia, la observancia de la juridicidad importará en ambos sentidos.

\section{La detención como afectación de derechos fundamentales.}

La libertad personal es susceptible de afectación ${ }^{82}$. Cuando tal afectación

privaciones de libertad realizadas por agentes del Estado en el contexto de un posible proceso penal".

${ }^{78}$ Tanto como la detención del "sentenciado a penas privativas de libertad que hubiere quebrantado su condena”, contemplada en el artículo 129 inciso 4 CPP. Hay que tener presente que la Constitución emplea como sinónimos los términos "detención" y “aprehensión”, según se desprende del artículo 81 C.Pol.. Cfr. Pujadas Tortosa, Virginia, Teoría general de las medidas cautelares penales (Marcial Pons, Madrid, 2008), p. 80. En palabras de la autora: "La tutela cautelar penal alcanza los peligros relativos a la cognición y a la ejecución: asegurar la ejecución de una eventual sentencia condenatoria es, de hecho, el cometido más genuino e indiscutido (en el orden penal y civil) de las medidas de aquel género". Cfr. Maturana Miquel, Cristián - Montero López, Raúl, Derecho procesal penal (LegalPublishing, Santiago, 2010), I, p. 426; HoRvitz, M. I - López, J., cit. (n. 62), I, p. 377.

${ }^{79}$ Cfr. Arias Vicencio, C, cit. (n. 62), p. 244.

${ }^{80}$ Marín González, J. C., cit. (n. 76), p. 28.

${ }^{81}$ Arias Vicencio, C., cit. (n. 62), p. 236.

${ }^{82}$ Cfr. Aldunate Lizana, E., Derechos, cit. (n. 2), pp. 225-226. Entiende por afectación "toda situación jurídica o material de detrimento en la posición jurídica o fáctica amparada por el contenido protectivo del respectivo derecho". Aclara que existen afectaciones amparadas por el ordenamiento jurídico, y otras que no lo están. En los lineamientos constitucionales de esta parte, seguiremos la estructura dada por el 
es concreta y recae sobre una persona determinada, se denomina doctrinalmente "intervención". La detención es una forma de afectación que, estimamos, puede reconducirse a la categoría de intervención. Siguiendo la perspectiva del derecho constitucional, se pueden señalar los requisitos que permiten establecer cuándo una detención es jurídicamente admisible, en tanto son los de toda intervención. Ellos son: a) la existencia de un fundamento o habilitación constitucional y, en su caso, de un fundamento legal para la afectación; b) la presencia de la finalidad prevista por el ordenamiento jurídico y; c) la proporcionalidad ${ }^{83}$.

a) La habilitación constitucional se encuentra establecida en el artículo $19 \mathrm{~N}^{\circ} 7$ C.Pol. ${ }^{84}$. En su letra b), señala: "Nadie puede ser privado de su libertad personal ni ésta restringida sino en los casos y en la forma determinados por la Constitución y las leyes" $"$. Con esto, la Constitución está indicando que ella misma señalará determinadas hipótesis y procedimientos que hacen jurídicamente posible la privación de libertad, a la vez que encomendará a la ley otras. Este último es un caso de "reserva legal" 86 , constitutivo de un límite a la facultad de afectar derechos fundamentales ${ }^{87}$. Opera como una garantía, que pretende evitar la afectación del derecho por un acto normativo particular ${ }^{88}$. Y, aunque parezca obvio, conviene recalcar que, tal habilitación legal, no confiere a la ley la posibilidad de contravenir lo ya normado constitucionalmente, cosa que deberá tenerse en cuenta sobre todo al examinar los "casos" en que es posible detener, dispuestos en el artículo $19 \mathrm{~N}^{\circ} 7 \mathrm{c}$ ) C.Pol. -ya que están dispuestos taxativamente- ${ }^{89}$, pero también en materia de "formas".

Para estos efectos, la doctrina constitucional admite que el término "ley" sea tomado en un sentido relativamente amplio. Además de la ley en su sentido formal, se comprenden aquí los tratados internacionales y los reglamentos de ejecución, aunque en cuanto a éstos no esté bien determinado el límite en que la ley puede dejar de regular, para encomendar el detalle al

profesor Aldunate, en el capítulo XII de su libro, sin perjuicio de otras referencias que se citarán oportunamente.

${ }^{83}$ Cfr. Nogueira Alcalá, H., (n. 62), II, p. 411. Señala los requisitos de las restricciones o privaciones de libertad.

${ }^{84}$ Aldunate Lizana, E., Derechos, cit. (n. 2), p. 230. Señala, específicamente, al artículo $19 \mathrm{~N}^{\circ} 7$, letras b) a d).

${ }^{85}$ En términos similares, que consideramos ajustados al precepto constitucional, se expresan los artículos 9.1 PIDCP., 7.2 CADH. y 5 inciso $1^{\circ} \mathrm{CPP}$.

${ }^{86}$ Nogueira Alcalá, H., (n. 62), II, p. 417.

${ }^{87}$ Aldunate Lizana, E., Derechos, cit. (n. 2), p. 257. Cfr. Nogueira Alcalá, H., (n. 2), I, pp. 104 ss.

${ }^{88}$ Aldunate Lizana, E., Derechos, cit. (n. 2), p. 257.

${ }^{89} \mathrm{Se}$ advertirá el problema a propósito del significado otorgado por la ley a la flagrancia. 
reglamento. Se excluyen, en cambio, los reglamentos autónomos y los decretos con fuerza de ley ${ }^{90}$. Ahora bien, el ministerio público puede impartir instrucciones generales a la policía para que ésta cumpla, sin orden previa, las funciones dispuestas en los artículos 83 a $85 \mathrm{CPP} .^{91}$. Consideramos que esta actividad es asimilable al reglamento de ejecución $-y$, en este punto, a la ley-, por su propio carácter general y atendido que el Ministerio Público cumple una función administrativa, no obstante su autonomía ${ }^{92}$. Lo dicho en este párrafo incidirá en el propio significado del término detención "ilegal". Un último punto a examinar es si acaso los actos administrativos dictados por funcionarios de determinados órganos o servicios, que tengan carácter general, pueden también estimarse como reflejo de la habilitación legal en sentido amplio y, por ende, ser considerados al tener que resolver sobre la juridicidad -ausencia de ilegalidad o arbitrariedad- de una detención. Estimamos que, en tanto dicho acto sea dictado en conformidad con la Constitución y la ley y tenga carácter obligatorio, también constituye una fuente que debe ser tomada en cuenta, pues de lo contrario su contenido quedaría reducido a una mera declaración ${ }^{93}$.

b) La finalidad de la afectación, entendemos que se identifica con los fines del procedimiento dispuestos en el artículo $19 \mathrm{~N}^{\circ} 7 \mathrm{e}$ ), inciso $1^{\circ}$, C.Pol. Éste dispone: "La libertad del imputado procederá a menos que la detención o prisión preventiva sea considerada por el juez como necesaria para las investigaciones o para la seguridad del ofendido o de la sociedad. La ley establecerá

${ }^{90}$ Aldunate Lizana, E., Derechos, cit. (n. 2), p. 257. Nogueira Alcalá, H., cit. (n. 2), pp. 104-115. Cordero Quinzacara, E., cit. (n. 1), p. 23. Cfr. Medina Quiroga, C., cit. (n. 36), pp. 40-42. Examina el alcance del término "ley" desde la perspectiva del artículo $30 \mathrm{CADH}$., asignándole un sentido restringido.

${ }^{91}$ Véanse los artículos 87 CPP. y 17 a) de la Ley No 19.640.

92 Véase: Aldunate Lizana, E., Derechos, cit. (n. 2), p. 189. Cfr. Chahuán SArrás, Sabas, Manual del nuevo procedimiento penal ( $4^{\mathrm{a}}$ edición, Santiago, Lexis Nexis, 2007), p. 217 ss. Reproduce instrucciones generales en materia de detención, que debe observar la policía. No interesa su vigencia o contenido puntual aquí, sino el observar cómo por esta vía se perfecciona el procedimiento establecido en términos más generales por la ley y, por ende, también se perfeccionan las propias garantías de la detención.

${ }^{93}$ Por ejemplo, la Orden General N² 2186 de 20 de mayo de 2008, dictada por el director general de la Policía de Investigaciones de Chile, dispone el Código de Ética de la institución. En su artículo 6 se refiere al principio de proporcionalidad, en los siguientes términos: "El personal de la Policía de Investigaciones de Chile comprometido con la vida humana, hace uso de la fuerza sólo cuando es estrictamente necesario y de manera proporcional, en defensa de su persona y derechos propios, como también de la persona y derechos de terceros, en la medida que asi lo exija el desempeño de sus funciones y el cumplimiento de la ley". 
los requisitos y modalidades para obtenerla" ${ }^{\prime 4}$. También, con lo prescrito en la letra c) del mismo artículo $19 \mathrm{~N}^{\circ} 7$, en la parte que indica: "Sin embargo, podrá ser detenido el que fuere sorprendido en delito flagrante, con el solo objeto de ser puesto a disposición del juez competente dentro de las veinticuatro horas siguientes".

c) La proporcionalidad es un principio que "examina la relación existente entre una medida de la autoridad, adoptada en el ámbito de sus facultades discrecionales, gravosa para sus destinatarios, y la finalidad perseguida por esa medida" 95 . Normalmente, se entiende integrada por tres aspectos: i) la idoneidad, consistente en que el medio empleado sea apto o apropiado para la obtención del fin perseguido; ii) la necesidad, consistente en que el medio empleado sea, dentro de otros igualmente eficaces, el menos gravoso; y iii) la proporcionalidad en sentido estricto, que busca establecer, en concreto, si el grado en que se afecta un derecho fundamental se encuentra justificado por el fin perseguido" ${ }^{96}$. Su falta se asocia, preferentemente, con la detención arbitraria.

En principio, la detención constituye una afectación del derecho fundamental a la libertad personal, que puede ser legítima o ilegítima, en tanto se cumplan o no las exigencias que acabamos de reseñar. Se la ha asociado, específicamente, con la privación de la "libertad ambulatoria" otro punto de vista, el "derecho a la seguridad individual" -que la doctrina constitucional entiende consagrado en las letras b) y siguientes del artículo 19 No 7 C.Pol.- se conforma por un conjunto de garantías específicas contempladas por la Constitución y que son funcionales a la realización de la libertad personal en general ${ }^{98}$. Desde la perspectiva procesal, la seguridad

${ }^{94} \mathrm{La}$ redacción actual, proveniente de la reforma introducida por Ley $\mathrm{N}^{a} 20.050$ de 26 de agosto de 2005, es de mala factura. Ello se debe a que el texto en general se mantuvo, cambiándose solamente la expresión "libertad provisional" por "libertad del imputado". Por eso, su parte final es discordante con la comprensión que hoy se tiene de las medidas cautelares frente a la libertad personal. Este derecho fundamental no posee requisito alguno. En cambio, su privación o restricción en el proceso penal, sí se sujeta a requisitos constitucionales y legales. Además, el texto dificulta la comprensión de los fines de la detención por flagrancia dado que, a diferencia de la letra c) de la misma disposición, señala que, quien debe estimar la concurrencia de necesidad de cautela, es únicamente el juez.

${ }^{95}$ Aldunate Lizana, E., Derechos, cit. (n. 2), p. 264.

${ }^{96}$ Aldunate Lizana, E., Derechos, cit. (n. 2), pp. 264-267. Véase: Nogueira AlCAlÁ, H., cit. (n. 62), II, p. 412.

${ }^{97}$ Horvitz, M. I - López, J., cit. (n. 62), I, p. 349. Nogueira Alcalá, H., cit. (n. 62), II, p. 409

${ }^{98}$ Nogueira Alcalá, H., cit. (n. 62), II, p. 407; Verdugo Marinkovic, M. Pfeffer Urquiaga, E. - Nogueira Alcalá, H., cit. (n, 75), I, p. 236; Evans de 
individual constituye un punto de partida para el desarrollo normativo de la protección de la libertad personal, que luego será complementado por la ley y otras fuentes jurídicas ${ }^{99}$ erigiéndose, por lo mismo, en la base del estatuto jurídico de la detención.

Pero además la detención, dependiendo de la manera en que se lleve a cabo, puede afectar otros derechos fundamentales. En doctrina, se encuentran referencias a la necesidad de una adecuada protección de la vida, de la integridad física y psíquica, de la salud y el honor del detenido. También de garantías judiciales; así, del derecho de defensa y sus manifestaciones particulares ${ }^{100}$, tales como la información o la incoercibilidad; o de la presunción de inocencia. Hay también alusiones genéricas a la dignidad de la persona ${ }^{101}$. Podríamos agregar más situaciones de posible afectación de otros derechos como, por ejemplo, en materia de integridad sexual.

También puede darse la situación inversa en que, mediante la afectación ilegítima de un derecho fundamental, se generen las condiciones para una detención. Por ejemplo, si durante una diligencia de entrada y registro se tortura al morador para que confiese dónde están las drogas que se buscan y así, una vez encontradas, detenerlo por delito flagrante.

LA CUAdra, Enrique, cit. (n. 75), p. 179. Silva Bascuñán, A., cit. (n. 21), XII, pp. 15 y 27.

${ }^{99}$ Sobre el derecho a la seguridad personal consagrado en el artículo 7 CADH., véase: Medina Quiroga, C., cit. (n. 36), pp. 212 ss.

${ }^{100}$ Dentro de la regulación que el artículo 31 de la Ley No 20.084 efectúa de la situación del adolescente detenido, se dispone: "El adolescente sólo podrá declarar ante el fiscal en presencia de un defensor, cuya participación será indispensable en cualquier actuación en que se requiera al adolescente y que exceda de la mera acreditación de su identidad". Véase resolución de la Corte de Apelaciones de San Miguel, de 4 de julio de 2007, rol N¹023-2007 REF. Confirma resolución del juez de garantía que declaró la ilegalidad de la detención de un menor, por haber sido éste sometido a una diligencia de reconocimiento sin estar presente su abogado defensor.

${ }^{101}$ Cfr. Nogueira Alcalá, H., cit. (n. 62), II, pp. 428, 430, 431, 434, 435. Con citas de jurisprudencia internacional. Silva Bascuñán, A., cit. (n. 7), XII, pp. 45, 49, 50. A propósito de los lugares de detención y de las condiciones de incomunicación. O’Donnell, Daniel, Derecho internacional de los derechos humanos (2a edición, Santiago, Editor Alejandro Valencia Villa, 2007), p. 334. Citando opinión consultiva No 8/87 de la Corte Interamericana de Derechos Humanos que indica que el "habeas corpus" "sirve no sólo para proteger la libertad, sino también la vida y la integridad de las personas privadas de libertad”. Medina Quiroga, C., cit. (n. 36), pp. 91-136, 137-168, 250 y 252; Bovino, A., cit. (n. 66), pp. 7, 31, 37 y 38; Cisterna Pino, Adolfo, La detención por flagrancia en el nuevo proceso penal (Santiago, Librotecnia, 2004), p. 63; Maturana Miluel, C. - Montero López, R., cit. (n. 78), I, p. 450; Arias Vicencio, cit. (n. 62), pp. 234 y 236; Salas Astraín, Jaime, Problemas del proceso penal (Santiago, Librotecnia, 2009), pp. 364, 367 y 385. 
Cabe plantearse, entonces, si la ilegalidad de la detención puede estar motivada en haberse afectado ilegítimamente derechos distintos de la libertad personal. Tal posibilidad, considerada por alguna doctrina como indiscutida ${ }^{102}$, creemos que tiene fundamento en el propio principio de supremacía constitucional consagrado en el artículo 6 C.Pol. La policía, en tanto órgano del Estado, debe someterse en su actuar a la Constitución y a las normas dictadas conforme a ella, en todo orden de cosas. También, se sustenta en el artículo 19 o 7 letra b) C.Pol., pues el cumplimiento de las "formas" constitucionales y legales para privar de la libertad, implican el respeto de las normas de procedimiento en general y no sólo las que digan relación, puntualmente, con la afectación de la libertad personal ${ }^{103}$. Entonces, por ejemplo, dar una golpiza en el calabozo a un detenido, provocándole lesiones, supone una infracción al artículo 6 C.Pol., relacionado con el artículo 19 No 1 C.Pol., el artículo 5 CADH. y los artículos 93 h) y 195 CPP. y, por otra parte, una infracción al artículo 19 № 7 b) C.Pol., el artículo 7.2 CADH. y el artículo 5 CPP., en tanto el ordenamiento jurídico en principio no contempla, como parte del procedimiento de detención, el lesionar al detenido en el recinto policial. En consecuencia, se trataría de un caso de detención ilegal. Pero esta materia necesariamente debe examinarse a la luz de la regulación de cada derecho fundamental implicado, para determinar exactamente qué se permite, y en qué medida, a los agentes que operan la detención. Si el mismo detenido aprovecha un descuido para huir del recinto y un carabinero usa el arma de servicio en su contra, lesionándolo, al menos desde la perspectiva penal la ley dispone que el policía pudiera verse favorecido por una causal de justificación ${ }^{104}$. En consecuencia, la ley permite herir al detenido concurriendo determinadas condiciones y así, no obstante haberse afectado su integridad física durante el tiempo de la detención, al momento de controlarse, ésta debiera ser considerada legal ${ }^{105}$.

${ }^{102}$ Piedrabuena Richard, Guillermo, Ley $N^{\circ} 20.253$ Agenda corta antidelincuencia (Santiago, Legis, 2008), p. 121. "Nadie discute que la declaración de ilegalidad de la detención es plenamente procedente cuando al imputado no se le hayan leído o respetado sus derechos o cuando se le ha sometido a tratos degradantes y contrarios a sus derechos fundamentales [...]".

${ }^{103}$ Volveremos sobre esto al tratar la detención ilegal "derivada".

${ }^{104}$ Según el artículo 411 del Código de Justicia Militar: "Estará también exento de responsabilidad penal, el Carabinero que haga uso de sus armas en contra del preso o detenido que huya y no obedezca a las intimaciones de detenerse./ Esto no obstante, los Tribunales, según las circunstancias y si éstas demostraren que no habia necesidad racional de usar las armas en toda la extensión que aparezca, podrán considerar esta circunstancia como simplemente atenuante de la responsabilidad y rebajar la pena en su virtud en uno, dos o tres grados". Novo A Monreal, E., cit. (n. 60), I, p. 402.

${ }^{105}$ El artículo 23 bis del Decreto-ley No 2.640, Orgánico de la Policía de Investi- 
En el desarrollo de la detención ilegal en conexión con otros derechos fundamentales interesarán, pensamos, la regulación particular de cada uno de ellos, el establecimiento de su posibilidad de afectación legítima, la consideración del llamado "contenido esencial" y las posiciones existentes a su respecto, los diversos intereses concurrentes y la posibilidad real de actuación, entre otros factores ${ }^{106}$. Este tema merece un estudio exclusivo.

\section{LA DETENCión CONTRARIA A DeRECho}

\section{La distinción entre detención ilegal y detención arbitraria.}

De las disposiciones de los tratados internacionales de derechos humanos, se desprende que la detención contraria a derecho puede ser de dos clases: ilegal o arbitraria. Esta distinción se realiza por la Convención americana de derechos humanos y por el Pacto internacional de derechos civiles y políticos ${ }^{107}$, de la manera siguiente ${ }^{108}$ :

a) La detención ilegal está dispuesta en el artículo 7.2 CADH.: "Nadie puede ser privado de su libertad fisica, salvo por las causas y en las condiciones fijadas de antemano por las Constituciones Politicas de los Estados Partes o por las leyes dictadas conforme a ellas". En términos similares, el artículo 9.1 PIDCP., prescribe: "Nadie podrá ser privado de su libertad salvo por las causas fijadas por la ley y con arreglo al procedimiento establecido en ésta". A ella destinaremos el apartado siguiente.

b) La detención arbitraria, por su parte, se contiene en el artículo 7.3 CADH.: "Nadiepuedeser sometido a detención o encarcelamiento arbitrarios".

gaciones de Chile (Diario Oficial de 24 de enero de 1979), dispone: "Estará exento de responsabilidad criminal, el funcionario de la Policía de Investigaciones de Chile, que con el objeto de cumplir un deber que establezca este decreto ley, se viere obligado a hacer uso de armas, para rechazar alguna violencia o vencer alguna resistencia contra la autoridad".

${ }^{106}$ Así, puede estimarse atentatorio en contra de varios derechos fundamentales el amarrar al detenido pero, ¿qué ocurre en caso que insista en autolesionarse en la celda? No debe afectarse el honor del detenido pero, estrictamente, cada persona que es sometida a un procedimiento de detención en público sufre cierta ignominia, no obstante presumirse inocente. Se deben informar los motivos y derechos al detenido, por la policía, pero ello no ocurrirá si el mismo ha quedado inconsciente o está intoxicado. Si un detenido está siendo trasladado al recinto policial y se fuga, no parece igual dispararle por la espalda a matar que a los pies y, aún, resulta distinto si se trata de un detenido por hurto de un par de frutas, que de un ladrón de un banco que acaba de matar al guardia y dos clientes, o si huyó armado o desarmado, etc.

${ }^{107}$ Véase también el artículo 37 letra b) de la Convención sobre los derechos del niño.

${ }^{108}$ Bovino, A., cit. (n. 66), p. 58; O’Donnell, D., cit. (n. 101), p. 282; Medina Quiroga, C., cit. (n. 36), p. 218 ss. 
La idea se contiene también en el artículo 9.1 PIDCP., en la parte que indica: "Nadie podrá ser sometido a detención o prisión arbitrarias".

Un primer modo de entender la arbitrariedad es en sentido genérico, como contrariedad al derecho, noción que es comprensiva de la ilegali$\mathrm{dad}^{109}$.

Pero, atendida la propia diferenciación establecida normativamente, y los diversos efectos que pueden generar una y otra, parece aconsejable deslindarlas ${ }^{110}$. Desde esta perspectiva, es arbitraria aquella detención que, no obstante ser legal, padece de un defecto de juridicidad que permite calificarla como tal. La Corte Interamericana de Derechos Humanos, comentando el artículo 7.3 CADH., ha indicado: "En el segundo supuesto, se está en presencia de una condición según la cual nadiepuede ser sometido a detención o encarcelamiento por causas y métodos que -aún calificados de legales-pueden reputarse como incompatibles con el respeto a los derechos fundamentales del individuo por ser, entre otras cosas, irrazonables, imprevisibles o faltos de proporcionalidad"11. De estos calificativos, el que cobra mayor fuerza doctrinariamente es el últi$\mathrm{mo}^{112}$. La afectación legítima de la libertad personal debe gozar del atributo de proporcionalidad que, a su vez, comprende las exigencias de idoneidad, necesidad y proporcionalidad en sentido estricto, antes referidas. Ya que la arbitrariedad se apreciará, desde este punto de vista, en situaciones de detención ajustada a la legalidad, ello significa que su ámbito característico será aquél en que los órganos estatales operan discrecionalmente ${ }^{113}$. Ejemplos de detenciones arbitrarias: $i$ ) siendo facultativa la detención en caso de ciertas faltas preferir ella, sin más, a la citación (artículo 134 inciso $4^{\circ} \mathrm{CPP}$.); ii) lo mismo, tratándose de simples delitos, si al funcionario a cargo del recinto policial se ofrecen garantías de comparecencia que desestima, inmotivadamente (artículo 134 inciso final CPP.); iii) pudiendo el fiscal dejar o no sin efecto la detención por delito flagrante, ordenar que se mantenga hasta

${ }^{109}$ O’Donnell, D., cit. (n. 101), pp. 283-286. El autor cita fallos de organismos internacionales en que se advierte esta forma de razonar. Arbitrario se equipara a irregular, abusivo, contrario a derecho.

${ }^{110}$ Bovino, A., cit. (n. 66), p. 34.

${ }^{111}$ Corte Interamericana de Derechos Humanos, sentencia del caso "Gangaram Panday vs. Surinam", de 21 de enero de 1994, párrafo 47.

${ }^{112}$ Sobre la proporcionalidad en materia de medidas cautelares, consúltese: DUCE Julio, Mauricio - Riego Ramírez, Cristián, Proceso Penal (Santiago, Editorial Jurídica de Chile, 2007), p. 266; Horvitz, M. I - López, J., cit. (n. 62), I, p. 459.

${ }^{113}$ Cfr. Aldunate Lizana, E., Derechos, cit. (n. 2), p. 191. Desarrolla la idea del "efecto reductivo que tienen las normas sobre derechos fundamentales en el ámbito de las potestades discrecionales del poder ejecutivo, y en especial de la administración". Es sugerente la vinculación que realiza entre aquél y los deberes de respeto y promoción, por una parte, y el principio de igualdad, por otra. 
la presentación del detenido ante el juez, a pesar de que resulta innecesaria (artículo 131 inciso $2^{\circ} \mathrm{CPP}$.); etc. ${ }^{114}$

Ahora bien, cuando la infracción a la proporcionalidad significa, al mismo tiempo, una infracción a la ley ${ }^{115}$, se tratará de una detención ilegal, y no meramente arbitraria. Esto ocurre, por ejemplo, con la prohibición general de detener por faltas: su razón radica en la ausencia de proporcionalidad, pero se establece legalmente en los artículos 124 y 134 CPP. Si se practica una detención por una falta -fuera de los casos que señala el artículo 134 inciso $4^{\circ}$ CPP.-, se infringen con ello las disposiciones relativas a los "casos" en que es factible detener, ya que la falta no habilita para dictar una orden judicial, ni su comisión flagrante permite que opere esta medida cautelar.

Cabe notar que, incluso, acatando la ley, se podría incurrir en detención arbitraria, si las propias disposiciones legales son las defectuosas en tal sentido $^{116}$.

Para la detención arbitraria no están previstos efectos, vinculados al proceso penal, en los tratados internacionales que la disponen. Habría que meditar si, acaso, del artículo 95 CPP. pueden extraerse ciertas consecuencias jurídicas a su respecto. Por otra parte, pensamos, queda abierta la posibilidad de que se declare la responsabilidad internacional del Estado infractor y, tratándose de leyes arbitrarias, de reclamar de su inconstitucionalidad, por no establecer éstas las garantías de un procedimiento racional y justo.

\section{Concepto y clasificación de la detención ilegal.}

Para efectos del proceso penal, detención ilegal es aquella que se realiza fuera de los casos y formas señalados por la Constitución y las leyes o, que se lleva a cabo sin existir un fin del procedimiento que la justifique o, en fin, aquella en que la verificación del caso que la autoriza ha sido posible como consecuencia de un acto no ajustado a derecho.

Lo primero que debe advertirse es que, no obstante su denominación, la detención ilegal no es, solamente, aquella en que se ha contravenido lo dispuesto en la ley, entendida en su sentido formal, como la disposición

${ }^{114}$ No compartimos la calificación de las "detenciones masivas" como arbitrarias. El cumplimiento de las normas debe verificarse respecto de cada individuo detenido. En consecuencia, por ejemplo, si la policía detiene a un grupo de sujetos porque de entre ellos uno lanzó una piedra que causó daños, respecto de los demás la detención no se ajusta a las exigencias de flagrancia y es, por consiguiente, ilegal. Cfr. Nogueira ALCALÁ, H., cit. (n. 62), II, p. 412. MEdina Quiroga, C., cit. (n. 36), p. 223.

${ }^{115}$ Cfr. Horvitz, M. I. - López, J., cit. (n. 62), I, p. 460. Nos referimos a aquellas disposiciones legales que se pronuncian sobre criterios o situaciones específicas de proporcionalidad.

${ }^{116}$ Medina Quiroga, C., cit. (n. 36), p. 221. Cfr. O’Donnell, D., cit. (n. 101), p. 293. 
emanada del órgano constitucionalmente competente y habiéndose seguido el procedimiento, también constitucional, para su formación. Tal como se ha indicado al tratar de los requisitos para realizar intervenciones legítimas de derechos fundamentales, en materia de libertad personal existe una regulación constitucional que establece determinados contenidos mínimos estimados particularmente importantes y, por lo mismo, elevados a un rango superior al legal. Sería absurdo, entonces, pretender que la contravención al mandato constitucional no es fuente de detención ilegal ${ }^{117}$. Luego, se ha indicado que, en materia de intervenciones, puede existir regulación por otras fuentes jurídicas si existe una habilitación para ello. Tal habilitación está dada por el artículo 19 № 7 letra b) C.Pol. Esta disposición se refiere a la "ley" pero, hemos dicho, la doctrina confiere al término "ley", en este ámbito, un sentido amplio. En consecuencia, la contravención a lo dispuesto en tratados internacionales de derechos humanos, leyes en sentido formal, reglamentos de ejecución ${ }^{118}$ e instrucciones generales del ministerio público, constituye fuente de detención ilegal ${ }^{119}$. También, la infracción de normas con carácter general dispuestas en virtud de otros actos administrativos. Esta manera de entender el término que se comenta es coherente con lo dispuesto en el artículo 6 inciso $1^{\circ} \mathrm{C}$.Pol. pues, lógicamente, los agentes que materializan la detención no sólo deben sujetarse a la ley, sino a toda norma dictada conforme a la Constitución ${ }^{120}$.

${ }^{117}$ Verdugo Marinkovic, Mario - Pfeffer Urquiaga, Emilio - Nogueira AlCalá, H., cit. (n. 75), I, p. 237. Comentando la redacción del artículo $19 \mathrm{~N}^{\circ} 7$ letra b) C.Pol., sostienen: “La expresión 'Constitución' fue agregada en el nuevo texto por indicación de don Alejandro Silva Bascuñán, quien recordó que varias de las normas reglamentarias de la detención se encontraban enunciadas en la Carta Fundamental”. Véase: O’Donnell, Daniel, cit. (n. 101), p. 293, quien cita jurisprudencia internacional que declara ilegal la detención "por el incumplimiento de una disposición constitucional que reconocía el derecho de la familia a ser informada de la detención de un pariente".

${ }^{118}$ Véanse, por ejemplo, los artículos 4, 17, 18, 19 del DS No 41 de 1987: Reglamento Orgánico de Policía de Investigaciones de Chile; los artículos 77, 135 y 136 del DS 1378 de 2007, reglamento de la Ley Na 20.084; el Decreto supremo No 518 de 1998, Reglamento de Establecimientos Penitenciarios.

${ }^{119}$ Cfr. Medina Quiroga, C., cit. (n. 36), p. 219: "La exigencia de legalidad implica la necesidad de que existan en cada Estado normas con categoría de ley que regulen todo lo referente a la privación de libertad, desde las causales que la permitan hasta el procedimiento a que debe sujetarse la acción de privar de libertad a una persona”. Bovino, A., cit. (n. 66), p. 33. Al respecto, sólo cabe opinar que, mientras no se cumpla con esta expectativa de regular todo aspecto de la detención por fuente legal, es forzoso conceder al término "ley" el sentido amplio referido.

${ }^{120}$ Cfr. Cea Egaña, J. L., cit. (n. 12), I, pp. 249-250. 
Del concepto propuesto fluye una clasificación. Hemos de distinguir entre la detención ilegal "originaria” y la "derivada”.

a) Detención ilegal originaria es aquella en que el incumplimiento dice relación, propia o estrictamente, con las normas que constituyen el estatuto jurídico de la detención. Por consiguiente, es la que no se realiza en los casos y formas señalados por la Constitución y las leyes o, que se lleva a cabo sin existir un fin del procedimiento que la justifique. La infracción a la legalidad se radica en sí misma, no en actos que la precedan haciéndola posible. Por ejemplo, la detención practicada por delito flagrante, sin existir ninguna hipótesis del artículo 130 CPP. o, la detención en que se presenta al detenido ante el juez ya transcurrido el plazo de 24 horas establecido como máximo.

b) Detención ilegal derivada es aquella en que la situación de detención ha sido posible, sólo mediante una infracción de normas jurídicas distintas de las que conforman el estatuto de la detención. En este caso la detención, observada aisladamente, no se ha llevado a cabo infringiendo, en sentido estricto, su estatuto jurídico. Pero, de no haberse vulnerado otras disposiciones, no se habría generado la situación que posibilitó la detención. Por ejemplo, la detención por delito flagrante de porte ilegal de arma de fuego -artículo 130 a) CPP.-, que ha quedado en evidencia con ocasión del registro ilegal, practicado dentro del procedimiento de control de identidad ilegal, en que no existe un caso fundado para realizarlo, de conformidad con el artículo 85 inciso $1^{\circ} \mathrm{CPP}$. En la definición de detención ilegal, la derivada corresponde a aquella en que la verificación del caso que la autoriza ha sido posible como consecuencia de un acto no ajustado a derecho.

En una situación concreta, pueden concurrir ambas clases de defectos ${ }^{121}$. La utilidad de la clasificación radica en la posibilidad de sistematizar distintos grupos de casos y fundar, jurídicamente, la inclusión de todos ellos dentro de la categoría de las detenciones ilegales en el proceso penal. Ambas especies se analizarán a continuación en apartados distintos.

\section{LA DETENCIÓN ILEGAL ORIGINARIA POR INOBSERVANCIA DE}

\section{CASOS Y FORMAS}

Se ha distinguido entre un aspecto material y un aspecto formal de la detención, razonamiento al parecer proveniente del derecho internacio-

${ }^{121}$ Por ejemplo, se practica una entrada y registro en lugar cerrado sin autorización, y gracias a ello se encuentra material pornográfico que no se ajusta a la definición del artículo 366 quinquies CP., deteniéndose al morador por delito flagrante de almacenamiento de pornografía infantil. 
nal $^{122}$. En clave constitucional, el primero se refiere a los casos, el segundo, a las formas ${ }^{123}$.

\section{Los casos de detención y su infracción.}

Nuestra Constitución habla de "casos" donde los tratados internacionales dicen "causas"124. Luego, se trata de aquellas situaciones o hipótesis que el ordenamiento jurídico ha considerado, como presupuestos, para llevar a cabo una privación de libertad legítima a título de detención ${ }^{125}$. Los tratados internacionales no establecen en su articulado casos, dejando entregado su establecimiento al derecho interno ${ }^{126}$. En Chile, la Constitución se ha pronunciado ya al respecto, señalando dos casos, instituyendo así una garantía en cuanto a ello. Está vetado a las fuentes jurídicas de jerarquía inferior, establecer hipótesis adicionales a las dispuestas por ella, o ampliar su contenido.

Los casos en que es posible efectuar la detención de una persona son dos: por existir una orden de funcionario público competente y, por delito flagrante $^{127}$.

Situándonos en la perspectiva de la ilegalidad, existen determinadas infracciones que dicen relación con requisitos generales aplicables a cualquier caso. Así, será ilegal la detención -ya sea que se argumente orden o flagrancia-, si no existe delito (hecho punible) o participación del imputado en él ${ }^{128}$. También si se detiene por un delito de aquellos en que la detención es improcedente ${ }^{129}$. A este respecto, deberán observarse las disposiciones

${ }^{122}$ O’Donnell, D., cit. (n. 101), pp. 291-292; Medina Quiroga, C., cit. (n. ), p. 219; Bovino, A., cit. (n. 66), p. 66. El párrafo 47 de la sentencia del caso "Gangaram Panday", ya aludido, señala respecto del artículo $7 \mathrm{CADH}$.: "Esta disposición contiene como garantías específicas, descritas en sus incisos 2 y 3 , la prohibición de detenciones o arrestos ilegales o arbitrarios, respectivamente. Según el primero de tales supuestos normativos, nadie puede verse privado de la libertad personal sino por las causas, casos o circunstancias expresamente tipificadas en la ley (aspecto material), pero, además, con estricta sujeción a los procedimientos objetivamente definidos por la misma (aspecto formal)".

${ }^{123}$ Cfr. Arias Vicencio, C., cit. (n. 62), p. 236.

${ }^{124}$ Cfr. los artículos $19 \mathrm{~N}^{\circ} 7$ b) C.Pol.; 9.1 PIDCP. y 7.2 CADH.

${ }^{125}$ Cfr. Bovino, A., cit. (n. 66), pp. 32 y 66.

${ }^{126}$ Según el artículo 7.2 CADH., deben establecerse de antemano por las constituciones políticas de cada Estado o por las leyes dictadas conforme a ellas.

${ }^{127}$ Artículo $19 \mathrm{~N}^{\circ} 7$ letra c) C.Pol.: "Nadie puede ser arrestado o detenido sino por orden de funcionario público expresamente facultado por la ley [...]. Sin embargo, podrá ser detenido el que fuere sorprendido en delito flagrante [...]"

${ }^{128}$ Cfr. Durán Fuica, Rodrigo, Medidas cautelares personales en el proceso penal (2a edición, Santiago, Librotecnia, 2007), p. 153.

${ }^{129}$ Véase abajo lo dicho acerca del error de derecho, a propósito del juicio acerca de la de legalidad de la detención. 
sobre la exclusividad de la citación (artículos 124 y 134 CPP.) ${ }^{130}$ y atender al hecho que, legalmente, la regla es que no quepa la detención imputativa tratándose de delitos de acción penal privada ${ }^{131}$.

Nos referiremos a continuación a los casos constitucionalmente dispuestos, deteniéndonos en ciertos temas que consideramos relevantes en materia de ilegalidad.

a) La orden de detención. Este caso constituye la regla general en nuestro ordenamiento jurídico ${ }^{132}$. La detención por orden está revestida de mayores garantías, porque el funcionario público debe realizar un control a priori de los motivos que la fundan y los fines perseguidos con ella, para luego decidir si la ordena o no.

Nuestra Constitución ha dejado abierta la posibilidad de que distintos sujetos sean habilitados para dictar órdenes de detención, al señalar que éstas deben provenir de un "funcionario público expresamente facultado por la ley". Sin embargo, la tónica del legislador procesal penal ha sido la supresión de las disposiciones que permitían ordenar la detención, a personas distintas del juez ${ }^{133}$. En concreto, generalmente existirá una resolución judicial del juez de garantía que ordene la detención y, por consiguiente, de él provendrá el mandamiento, el encargo para que dicha resolución sea ejecutada legalmente. También la orden puede provenir del tribunal de juicio oral en lo penal ${ }^{134}$.

El juez que dicta la orden debe ser competente ${ }^{135}$. En materia penal, además de las disposiciones del Código Orgánico de Tribunales, en este punto interesa el artículo $72 \mathrm{CPP}$. que, en caso de contienda de competencia entre jueces de garantía, entrega a cada uno de ellos la facultad de realizar actuaciones urgentes y otorgar autorizaciones al ministerio público.

${ }^{130}$ Cfr. Horvitz, M. I. - López, J., cit. (n. 62), I, pp. 359 y 373.

${ }^{131}$ Cfr. Cisterna Pino, A., cit. (n. 101), pp. 37-38. A sus argumentos, cabe agregar que, tratándose de órdenes judiciales, el artículo 127 inciso 1 CPP. restringe su solicitud al ministerio público, que no es interviniente en los procesos por esta clase de delito.

${ }^{132}$ Cisterna Pino, A., cit. (n. 101), p. 20.

${ }^{133}$ Durán Fuica, R., cit. (n. 128), p. 159. Cfr. Maturana Miguel, C. - MonTero López, R., cit. (n. 78), p. 481; Horvitz, M. I. - López, J., cit. (n. 62), I, pp. 351 y 370; Cisterna Pino, A., cit. (n. 101), p. 35. Cita como caso excepcional en que la orden puede ser dictada por otra autoridad -en éste, el Presidente de la República- el del estado de sitio, actualmente contenido en el artículo 43 inciso 2 C.Pol.; Bovino, A., cit. (n. 66), p. 9. Según expone, que la orden deba provenir de un juez constituye un estándar impuesto por la jurisprudencia internacional.

${ }^{134}$ Chahuán Sarrás, S., cit. (n. 92), p. 209.

${ }^{135}$ Sobre la declaración de ilegalidad debida a orden dictada por tribunal incompetente, en el ámbito internacional, O’DonNell, D., cit. (n. 101), p. 301. 
La orden de detención tiene como destinatario a la policía ${ }^{136}$, por lo que cabría estimar la ilegalidad si es practicada por otro sujeto.

La orden debe ser intimada en la forma legal ${ }^{137}$. Intimar significa exigir su cumplimiento ${ }^{138}$. Para que dicho término sea adecuadamente dimensionado, es preciso recordar que la Constitución exige que primero se realice la intimación de la orden y después se lleve a cabo la detención. No es una formalidad neutra, sino con un sentido de garantía ${ }^{139}$, pretende dar al sujeto la oportunidad de conocer la existencia real de una orden y de quién proviene, saber su motivo, ejercer actos de defensa -como identificarse adecuadamente para vencer un error de identidad, por ejemplo- $y$, en fin, optar por entregarse voluntariamente o resistirse al acto ${ }^{140}$.

Estas ideas son coherentes con el esquema tradicional, que supone el despacho de un mandamiento u orden escrita. Ésta debe cumplir con los requisitos del artículo $154 \mathrm{CPP}$., y es la que puede materialmente ser exhibida, de conformidad con el artículo 94 a) $\mathrm{CPP}^{141}$. En el caso de las órdenes otorgadas por otros medios, incluso verbales, según establece el artículo 9 inciso 3 CPP., cabe concluir que la intimación legal consiste en la entrega previa de una constancia policial de la existencia de una orden de detención, con el contenido que tal disposición señala ${ }^{142}$.

${ }^{136}$ Horvitz, M. I. - López, J., cit. (n. 62), I, p. 367.

${ }^{137}$ Artículo $19 \mathrm{~N}^{\circ} 7$ c) C.Pol.

${ }^{138}$ Para la Real Academia de la Lengua Española, en la acepción pertinente: "Requerir, exigir el cumplimiento de algo, especialmente con autoridad o fuerza para obligar a hacerlo".

${ }^{139}$ Horvitz, M. I. - López, J., cit. (n. 62), I, p. 368.

${ }^{140}$ Silva Bascuñán, A., cit. (n. 7), XII, p. 36; Nogueira Alcalá, H., cit. (n. 62), II, p. 421.

${ }^{141}$ Se habla también del derecho del detenido a obtener copia de la orden. Así SiLva Bascuñán, A., cit. (n. 7), XII, p. 35; Maturana Mieuel, C. - Montero López, R., cit. (n. 78), p. 464. Aunque no haya texto expreso, salvo en el caso de incomunicación, pensamos que puede ello resultar exigible por parte de los jueces, al menos como una forma de realizar mejor el derecho de defensa, y de conformidad con el texto del artículo $8 \mathrm{CADH}$.

${ }^{142}$ Durán Fuica, R., cit. (n. 128), p. 170; Salas Astraín, J., cit. (n. 101), p. 383. A nuestro juicio la desprotección se hace evidente al disponerse la entrega de una mera constancia carente de formalidades, por parte de quien detiene. Semejante proceder, permitido por la ley, no otorga al ciudadano grado alguno de certeza respecto de quién le intima la detención -si un policía o un secuestrador- ni de existir realmente una orden y un motivo para ella. Consideramos que aquí, la interpretación restrictiva dispuesta por el artículo 5 inciso $2^{\circ} \mathrm{CPP}$. debe tomarse en cuenta, al momento de calificar los "casos urgentes" en que la orden no escrita sea "indispensable para el éxito de la diligencia”. Esto con mayor razón, en la medida que la policía cuente con medios de recepción de documentación electrónica. 
Sería ilusorio pretender que toda detención deba estar precedida de intimación al imputado. Muchas veces, la policía tendrá que proceder de inmediato a privar de libertad, sin exhibición de la orden o entrega de la constancia en forma previa. Pero en estos casos le será exigible al órgano de persecución justificar y, de ser necesario, acreditar, la imposibilidad de proceder de conformidad con la Constitución y la ley, como se dirá.

Un tema debatido ha sido el de la exigencia de supuesto material ${ }^{143}$ en la detención por orden judicial. Se sostiene que ella sería inexistente, dado que el texto del artículo 127 CPP., en ninguno de sus incisos, alude a la necesidad de justificar por el solicitante la existencia de un hecho punible y de participación en él de la persona respecto de quien se pide la orden ${ }^{144}$. Esto hace, incluso, que cierta doctrina se cuestione el carácter de medida cautelar de la detención por orden judicial ${ }^{145}$.

Comenzaremos por la hipótesis del artículo 127 inciso $1^{\circ} \mathrm{CPP} .{ }^{146}$. De la sola disposición no se desprende la exigencia de supuesto material, pero ella sí se obtiene claramente de un examen sistemático de ciertas normas. Así, el ministerio público debe solicitar la orden de detención ${ }^{147}$; ello únicamente se explica en la medida que el juez de garantía opere como contralor de los derechos del afectado pues, si no, lo más práctico habría sido conceder al fiscal el poder de emplear directamente la fuerza pública ${ }^{148}$. La orden se dirige en contra del imputado, persona a quien se atribuye participación en un hecho punible (artículo 7 CPP.), de aquí que el juez deba recabar antecedentes bastantes para considerar que existe tal hecho, y que la persona a quien se pretende privar de libertad ha intervenido en él ${ }^{149}$. Sólo así podrá

143 "Fumus commissi delicti".

${ }^{144}$ Silva Bascuñán, A., cit. (n. 21), XII, p. 34. Marín GonZález, J. C., cit. (n. 76), p. 24.

${ }^{145}$ Tavolari Oliveros, R., cit. (n. 48), p. 287; Maturana Miluel, C. - MonTERo López, R., cit. (n. 78), p. 462.

${ }^{146}$ La disposición señala: "Salvo en los casos contemplados en el artículo 124, el tribunal a solicitud del ministerio público, podrá ordenar la detención del imputado para ser conducido a su presencia, sin previa citación, cuando de otra manera la comparecencia pudiera verse demorada o dificultada".

${ }^{147}$ Horvitz, M. I.- López, J., cit. (n. 62), I, p. 367; Maturana Miquel, C. Montero López, R., cit. (n. 78), p. 461. Chahuán Sarrás, Sabas, cit. (n. 92), p. 209.

${ }^{148}$ Cfr. Maturana Miluel, C. - Montero López, R., cit. (n. 78), p. 427. En virtud de la presunción de inocencia del imputado, la carga de acreditar el supuesto material en materia de medidas cautelares recae en el fiscal (solicitante). Por lo mismo, no son admisibles las cautelares decretadas de pleno derecho. Durán FuiCA, R., cit. (n. 128), p. 174.

${ }^{149}$ Durán Fuica, R., cit. (n. 128), p. 160. "En el nuevo proceso penal, esta medida sólo puede recaer sobre la persona del imputado, es decir, sobre aquella persona a la 
dictar una resolución fundada (artículo 36 CPP.) que, luego, se reproducirá en lo pertinente en el mandamiento [artículo 154 b) CPP., que debe señalar el motivo de la detención] ${ }^{150}$ o en la constancia (artículo 9 inciso $3^{\circ}$ CPP, que debe indicar el "delito" que le sirve de fundamento) ${ }^{151}$, de manera que al efectuarse la intimación el imputado pueda ver realizado su derecho a la información [artículos 94 letra a) y 9 inciso 3 CPP.] y, como hemos examinado, a ejercer en general su defensa. Más tarde, sólo este proceder permitirá un adecuado control de la legalidad de la detención, tanto por el juez de garantía -que, estimamos, es competente para apreciar a posteriori y con más detenimiento la veracidad y exactitud de los antecedentes que le fueron expuestos al solicitarse la orden-, como por la vía del amparo constitucional, si es del caso ${ }^{152}$.

Entender lo contrario, es decir, que legalmente a una persona se la pudiese privar de libertad y traer compulsivamente a un tribunal, en calidad de imputado, sin requerirse para ello antecedentes sobre la existencia del hecho punible y la participación, implicaría que la disposición legal que lo permite sería objetable en cuanto a su constitucionalidad, porque evidentemente

cual se le atribuye participación en un hecho punible. En otras palabras, sobre aquella persona respecto de la cual existe un juicio de imputabilidad (fumus boni juris), el que debe formarse directamente en el sujeto que practica la detención, o bien en el juez de garantía, que es quien la ordena”. La raíz de esta necesaria vinculación del imputado a un hecho, en materia de medidas cautelares, se explica desde la propia teoría del objeto del proceso penal. Cfr. Maturana Mieuel, C. - Montero López, R., cit. (n. 78), p. 423.

${ }^{150}$ CASTro Jofré, Javier, Introducción al derecho procesal penal chileno (Santiago, LexisNexis, 2006), p. 268. Señala que: "por motivo debe entenderse el hecho que la justifica". Ahora bien, la ley prescribe la expedición del mandamiento con cierto contenido predeterminado que existe para la realización, cuando menos, del derecho de defensa. Por eso, la disposición debe interpretarse restrictivamente, lo que aquí, implica asignarle un sentido lo menos perjudicial para el imputado. Esto equivale a atribuirle al "motivo" todo el contenido posible que constituya información relevante. En suma, tanto la expresión del "fumus commissi delicti" como del "periculum in mora", que debieran, en todo caso, ya figurar en la resolución que ordenó la detención.

${ }^{151}$ Como ocurre en general durante el proceso, más que la expresión de calificaciones jurídicas, interesa la del hecho punible. Estimamos que es una situación análoga a la de los artículos 140 b) y 229 CPP. Cfr. Soto Simpson, María Cristina, La importancia de la fundamentación de la orden de detención escrita (Memoria para optar al grado de Licenciada en Ciencias Jurídicas, Pontificia Universidad Católica de Valparaíso, 2011), pp. 17 ss. Realiza una crítica al contenido del mandamiento.

${ }^{152}$ Incluso, como la orden de detención no escapa al régimen general de las resoluciones judiciales, también queda abierta aquí la posibilidad de formular un incidente de nulidad que, en la situación que analizamos, creemos permitiría conectar la falta de fundamentación con la presunción de derecho del perjuicio dispuesta en el artículo 160 CPP. 
no estaría estableciendo las garantías de un procedimiento racional y justo (artículo 19 No 3 C.Pol.) $)^{153}$.

En cuanto al artículo 127 inciso 2 CPP. ${ }^{154}$, estimamos que su rol es precisar la hipótesis en que puede ser dictada una orden de detención, respecto del imputado legalmente citado y que no ha comparecido injustificadamente al tribunal. Ello sólo puede ocurrir cuando su presencia en una audiencia judicial sea condición de ésta ${ }^{155}$. Así, se armoniza esta disposición con los artículos 33 y 123 CPP. ${ }^{156}$. Se ha sostenido que esta detención es, en realidad, un arresto ${ }^{157}$. No compartimos tal apreciación dado que, desde la perspectiva constitucional, como se ha indicado, ya están perfilados de manera diferente detención y arresto ${ }^{158} \mathrm{y}$, por otra parte, el artículo 33, que debe ser considerado sistemáticamente para ilustrar el sentido del artículo 127 inciso $2^{\mathrm{o} 159}$, distingue claramente entre la incomparecencia del imputado, que puede ser detenido o sometido a prisión preventiva, y la de testigos, peritos y otras personas, que pueden ser arrestados y multados ${ }^{160}$. De esto se concluye que el artículo $124 \mathrm{CPP}$., en su redacción original, se refería ya, erróneamente, al "arresto por falta de comparecencia, de acuerdo con lo dispuesto en el articulo 33", en cuanto al imputado, puesto que dicho artículo 33 nunca ha

${ }^{153}$ Cfr. Horvitz, M. I. - López, J., cit. (n. 62), I, p. 365. Enfoca el problema de la inconstitucionalidad desde la perspectiva de infracción al artículo $19 \mathrm{~N}^{\circ} 7 \mathrm{~b}$ ) C.Pol. También Maturana Miluel, C. - Montero López, R., cit. (n. 78), p. 463.

${ }^{154}$ Señala la disposición: "También se decretará la detención del imputado cuya presencia en una audiencia judicial fuere condición de ésta y que, legalmente citado, no compareciere sin causa justificada".

${ }^{155}$ Por ejemplo, véanse los artículos 229, 142 inciso 3 -en relación con el artículo 155 inciso final-, 237, 241, 285, 406 y 393 CPP. En cambio, no está obligado a comparecer, aunque sea citado, por ejemplo, tratándose de las audiencias indicadas en los artículos 10, 98, 249 y 346. En este sentido, resolución de la Corte de Apelaciones de Punta Arenas, rol N ${ }^{\circ} 4-2005$, de 14 de enero de 2005.

${ }^{156}$ De lo contrario, habría que entender que, en cualquier caso, podría estimarse que la presencia del imputado es necesaria (artículo $123 \mathrm{CPP}$.), procediendo así siempre -y en buenas cuentas, al arbitrio del tribunal- la orden de detención por el hecho de la incomparecencia del citado (artículo 33 inciso $3^{\circ}$ CPP.). Visto de este modo, el artículo 127 inciso $2^{\circ}$ no tendría utilidad.

${ }^{157}$ Horvitz, M. I.- López, J., cit. (n. 62), I, p. 360.

${ }^{158}$ Específicamente sobre el significado del arresto, Verdugo Marinkovic, M. - Pfeffer Urquiaga, E. - Nogueira Alcalá, H., cit. (n. 75), I, p. 238. Silva BasCUÑán, A., cit. (n. 21), XII, p. 31. Debe de todos modos advertirse la vaguedad que reina al respecto. Pero recuérdese que, precisamente, el Constituyente se empeñó en diferenciarlo de la detención, terminológica y conceptualmente.

${ }^{159}$ Véase el artículo 22 del Código Civil.

${ }^{160}$ Durán Fuica, R., cit. (n. 128), p. 157; Maturana Miluel, C. - Montero López, R., cit. (n. 78), p. 455. 
dispuesto su procedencia, sino la de la detención o la prisión preventiva ${ }^{161}$. Y que este error subsiste y se ha tornado en total confusión, en el actual inciso 2 del artículo 124, al aludirse indiscriminadamente a "el arresto por falta de comparecencia, la detención o la prisión preventiva" del imputado ${ }^{162}$. Y no al revés, que de dicho artículo 124 deba derivarse una interpretación de las normas legales pertinentes del Código Procesal Penal que equiparen la detención y el arresto.

Si podemos sostener que este caso de detención continúa siendo una medida cautelar ${ }^{163}$, y que el arresto no lo es ${ }^{164}$-cosa que por lo demás es coherente con la sistemática de nuestro Código, que no incluye al arresto dentro de las medidas cautelares-, no consideramos fructífero equiparar ambos en este punto, más aún teniendo en cuenta que el arresto es una institución que tiene un estatuto deficiente ${ }^{165}$. Y si se trata de una medida cautelar, el requisito del "fumus commissi delicti" debe estar presente, al igual que en el caso anterior, y para los mismos fines de garantía ${ }^{166}$.

${ }^{161}$ Resulta interesante preguntarse si realmente cabe la orden de prisión preventiva respecto del imputado citado que no comparece. Estimamos que no, dado que ella siempre debe decretarse en audiencia, previo debate, con la presencia del imputado (artículo 142 inciso 3 CPP.). Además, habrá muchos casos de citación que buscan la comparecencia del imputado a la audiencia de formalización de la investigación y, lo propio, es que la prisión preventiva quepa sólo una vez que se han formulado cargos al imputado (artículos 140 y 230 CPP.). En consecuencia, creemos que debiera dictarse la orden de detención y, ya en la audiencia, solicitarse la prisión preventiva. La única excepción, discutible, es el caso del acusado que no comparece a la audiencia de juicio oral, del artículo 141 inciso final CPP. El fundamento de este punto de vista se encuentra en que la prisión preventiva está concebida como una cautelar que requiere el debate previo de los intervinientes para su adecuada resolución y, por lo mismo, no cuenta con un mecanismo legal de control a posteriori.

${ }^{162}$ Cfr. Chahuán Sarrás, S., cit. (n. 92), p. 206. Distinta interpretación podría haberse obtenido, si se hubiese conservado el modelo de las disposiciones comentadas, según el Anteproyecto de Código Procesal Penal. Cfr. Maturana Miluel, Cristián (coordinador), Reforma procesal penal. Génesis, historia sistematizada y concordancias (Santiago, Editorial Jurídica de Chile, 2003), I, pp. 206, 610 y 623.

${ }^{163}$ Cfr. Horvitz, M. I. - López, J., cit. (n. 62), I, p. 376. Se estima que la hipótesis que se analiza es constitutiva de "detención judicial por incomparecencia del imputado o arresto". Pero se la reconoce como medida cautelar personal.

${ }^{164}$ Maturana Miquel, C. - Montero López, R., cit. (n. 78), p. 455

${ }^{165}$ Nogueira Alcalá, H., cit. (n. 62), II, p. 422.

${ }^{166} \mathrm{~A}$ pesar que doctrinariamente se ha diferenciado el caso del artículo 127 inciso $2^{\circ}$ CPP. de aquellos de "detención imputativa", hay situaciones en que su empleo es para los mismos efectos. Es lo que sucede cuando la orden se solicita respecto del imputado que no comparece a la audiencia de formalización de la investigación, o a la primera audiencia de procedimiento simplificado (en éste, el juez tendrá a la vista el requerimiento). Cfr. Horvitz, M. I.- López, J., cit. (n. 62), I, p. 365. 
De su solo texto parece desprenderse que la detención puede ser ordenada de oficio, cosa que estimamos bastante discutible -salvo el claro caso de la aprehensión-, atendido que lo regular es que a los jueces en materia penal se confiera, legalmente, la posibilidad de obrar de propia iniciativa en resguardo de los derechos del imputado u otros intervinientes y no al contrario. Además, la doctrina se pronuncia en materia de medidas cautelares, exigiendo la actividad del interesado ${ }^{167}$.

b) El delito flagrante. La detención de quien es sorprendido in fraganti es un caso característico del área cultural de la que se nutre nuestro derecho ${ }^{168}$. Pero en Chile resulta distintivo que el delito flagrante esté dispuesto a nivel constitucional y no sólo legal, lo que supone una tradición en nuestros textos fundamentales ${ }^{169}$.

El establecimiento del término "delito flagrante" en la Constitución, implica que no se ha habilitado de manera abierta o muy amplia al legislador para que, en este nivel inferior, precise cuándo la policía o un particular habrán de practicar la detención ${ }^{170}$. Se ha preferido tipificar el caso que se analiza mediante un término puntual, al que habrá que dotar de un cierto significado, más allá del cual no será posible ir. Es decir, que la Constitución disponga, específicamente, que sin existir una orden, la detención sólo cabe en virtud de delito flagrante, es una garantía de la libertad personal. El legislador no puede crear causas de detención y determinar, arbitrariamente, que ellas constituyen situaciones de flagrancia, en desmedro del derecho fundamental ${ }^{171}$.

${ }^{167}$ Véase la nota 145 . No creemos que la orden sólo pueda solicitarse por el fiscal. En primer lugar, la referencia al fiscal sólo está dispuesta en el inciso 1 del artículo 127. Por otra parte, esta clase de detención no opera únicamente con motivo de obtener la comparecencia para realizar una imputación formal; cabe la posibilidad de que se requiera en momentos en que el proceso esté más avanzado, y que en ellos sólo exista un acusador particular. Análoga situación se prevé, para la prisión preventiva, en el artículo 141 inciso final. Cfr. Horvitz, M. I. - López, J., cit. (n. 62), I, p. 376.

${ }^{168}$ Véanse el artículo 490 de la Ley de Enjuiciamiento Criminal Española y el artículo 382 del Código de Procedimiento Penal Italiano. En Chile, es el segundo y último caso en virtud del cual cabe detención. Cfr. García Morillo, Joaquín, El derecho a la libertad personal (Tirant lo Blanch y Universidad de Valencia, Valencia, 1995), pp. 108 ss. Da cuenta de la situación en España y esboza una perspectiva comparada.

${ }^{169}$ Cfr. Cisterna Pino, A., cit. (n. 101), pp. 30 ss.

${ }^{170}$ Compárese con el sistema español, en que los casos se determinan por la ley. El artículo 17.1 de la Constitución Española prescribe: "Toda persona tiene derecho a la libertad y a la seguridad. Nadie puede ser privado de su libertad, sino con la observancia de lo establecido en este artículo y en los casos y en la forma previstos en la ley". La disposición debe concordarse con los artículos 489 y siguientes de la Ley de Enjuiciamiento Criminal. Cfr. Maturana Miluel, C. - Montero López, R., cit. (n. 78), p. 472.

${ }^{171}$ Cfr. Aldunate Lizana, E., Derechos, cit. (n. 2), p. 186. Para el autor: “La ley 
Lo anterior supone plantearse si, en verdad, son constitucionales todas las hipótesis de flagrancia que establece el artículo $130 \mathrm{CPP} .{ }^{172}$. Las situaciones de flagrancia real están contenidas en las letras a) y b) de la disposición ${ }^{173}$. En ellas el hecho es ostensible para quien priva de libertad y hay genuina coetaneidad o inmediatez ${ }^{174}$. La primera se refiere a "el que actualmente se encontrare cometiendo el delito" y supone principio de ejecución de éste (al menos tentativa) ${ }^{175}$, a no ser que se trate de un caso de acto preparatorio especialmente penado ${ }^{176}$. De aquí que sea relevante el criterio que se emplee para señalar el comienzo de ejecución del delito, al delimitar la frontera entre legalidad e ilegalidad en este punto. La segunda establece la flagrancia de delito respecto de "el que acabare de cometerlo" y, aunque estrictamente el delito ha terminado, resulta lógico admitir todavía que el sujeto sea detenido in fraganti pues, de lo contrario, nunca cabría la posibilidad de detener por delito flagrante consumado ${ }^{177}$. Las restantes situaciones ya entran en el terreno de lo discutible; se trata de aquellas de flagrancia denominada ficta o virtual ${ }^{178}$, que operan sin que el agente de la detención haya percibido por sus sentidos el hecho punible, o sin que el hecho esté aún cometiéndose o apenas haya terminado, o ambas cosas. Sólo nos referiremos aquí a las situaciones de falta de ostensibilidad en la detención policial. Estimamos que cabe tolerarla,

es la encargada de desplegar una serie de elementos para asegurar y permitir el ejercicio concreto de ciertos derechos y libertades; pero la forma que elige para hacerlo no ciñe, ni petrifica, el contenido constitucional de la respectiva libertad, derecho o garantía. De lo contrario, se corre el riesgo de interpretar la Constitución a la luz del contenido (iusfundamental) desarrollado a nivel legislativo. Es así como se pervierte el orden de supremacía que fija la propia carta”.

${ }^{172}$ Cfr. Piedrabuena Richard, G., cit. (n. 102), pp. 108-120. Sintetiza el arduo debate al respecto, a propósito de la discusión del proyecto de la actual Ley 20.253. Precisamente, aquí se expresó la idea de interpretar la Constitución desde la ley, a propósito de la fijación de un plazo legal constitutivo de "tiempo inmediato" en que aún se entendería existir flagrancia: "El Senador Espina consideró que la fijación de un plazo no era inconstitucional porque la Constitución no definía lo que se entendía por delito flagrante y que por lo mismo el legislador ha cumplido la tarea que no está definida por la Constitución en todos los acápites del artículo 130 y no sólo en la ampliación de plazo del inciso final del artículo 130".

${ }^{173}$ Cisterna Pino, A., cit. (n. 101), p. 42; Durán Fuica, R., cit. (n. 128), p. 189. Para éste: "En sentido estricto, la flagrancia se produce cuando el autor de un delito es sorprendido cuando aún está realizando actos de ejecución propios del hecho, o inmediatamente después de haberlo consumado".

${ }^{174}$ Cfr. Cisterna Pino, A., cit. (n. 101), p. 43.

${ }^{175}$ Maturana Miquel, Cristián - Montero López, Raúl, cit. (n. 78), p. 472.

${ }^{176}$ Cisterna Pino, A., cit. (n. 101), p. 83.

${ }^{177}$ Cfr. Maturana Miluel, C. - Montero López, R., cit. (n. 78), p. 473.

${ }^{178}$ Cisterna Pino, A., cit. (n. 101), p. 43. 
vinculado esto al hecho que la Constitución permite la detención por delito flagrante efectuada por un particular. Cuando un particular detiene es él quien ha apreciado la situación de flagrancia; luego, si el particular -víctima, testigo- en vez de hacer uso de tal posibilidad prefiere signar al hechor y dejar entregada su aprehensión a la policía, no cabría hacer reproche fundado en que ésta no advirtió por sí misma el delito ${ }^{179}$.

Adicionalmente, hay que reparar en los casos señalados en el artículo 129 inciso $4^{\circ} \mathrm{CPP} .{ }^{180}$, que constituyen asimilaciones a flagrancia, por la vía legal. El sentenciado a pena privativa de libertad que quebranta, podría estar dentro de una genuina flagrancia del delito de quebrantamiento de condena, o no, dependiendo de la situación en que sea detenido. El que se fuga estando detenido, pensamos, continúa jurídicamente sujeto a la medida cautelar y su captura restablece el orden regular de $\operatorname{cosas}^{181}$. Quien tiene orden de detención pendiente debe ser detenido en virtud de ello, y conforme al procedimiento respectivo -habrá que realizar la intimación, en primer lugar-; la ley no puede disfrazar este caso como uno de flagrancia sin pasar por sobre la Constitución. La violación flagrante de medidas cautelares es una invención del legislador que consideramos incompatible con la Constitución, pues ésta admite sólo flagrancia de delito. La violación de la condición de suspensión condicional del procedimiento del artículo 238 b) CPP., es inadmisible por la misma razón. La disposición es un claro ejemplo de cómo el legislador tuerce el sentido constitucional del término. Se entiende que estos casos debieran, en parte reubicarse, en parte desaparecer.

La detención por flagrancia es excepcional ${ }^{182}$; la Constitución dispone que la regla general sea la detención en virtud de una orden. Es lógico que así sea, pues esta última está revestida de mayores garantías, atendida la confrontación entre un solicitante y un juez que decide decretarla, la necesidad de antecedentes para fundarla y de ciertas formalidades para llevarla a cabo. Luego, ante casos dudosos, lo que cabe es estimar que debió haberse obte-

${ }^{179}$ Cfr. Maier, Julio, Derecho procesal penal (Buenos Aires, Editores del Puerto, 2011), III, p. 374.

${ }^{180}$ Señala la disposición: "La policía deberá, asimismo, detener al sentenciado a penas privativas de libertad que hubiere quebrantado su condena, al que se fugare estando detenido, al que tuviere orden de detención pendiente, a quien fuere sorprendido en violación flagrante de las medidas cautelares personales que se le hubieren impuesto y al que violare la condición del artículo 238, letra b), que le hubiere sido impuesta para la protección de otras personas". Cfr. DuRán FuiCa, R., cit. (n. 128), pp. 179 ss.

${ }^{181}$ Esto, tratándose de hacer retornar al estado de privación de libertad a quien se acaba de fugar. Pero es objetable que la ley deje abierta la posibilidad de actuar la detención sin orden judicial, indefinidamente en el tiempo.

${ }^{182}$ Horvitz, M. I. - López, J., cit. (n. 62), I, p. 372; Cisterna Pino, A., cit. (n. 101), pp. 20 y 35. 
nido la orden correspondiente, criterio que es coherente con el mandato de interpretación restrictiva dispuesto en el artículo 5 inciso $2^{\circ} \mathrm{CPP}$.

\section{Las formas de la detención y su infracción.}

La detención sólo es posible jurídicamente en los casos indicados. Pero, además, el ordenamiento ha previsto un conjunto de formas, un procedimiento ${ }^{183}$, al que deben sujetarse estrictamente quienes la lleven a cabo, según se ha sostenido ${ }^{184}$. Lo anterior, en nuestro concepto, para un adecuado resguardo tanto de la libertad personal, como de otros derechos ${ }^{185}$.

$\mathrm{Al}$ examinar el procedimiento de la detención, se aprecia que existen exigencias en tres órdenes diversos, a saber, en cuanto al lugar, en cuanto al tiempo y en cuanto al modo de ejecutar esta clase de privación de libertad.

a) El lugar de la detención. La Constitución declara que una persona detenida sólo puede permanecer en tal estado en su casa o en lugares públicos destinados a tal objeto ${ }^{186}$. En principio no se divisa problema para estimar que se puede mantener a alguien detenido siempre en su casa, y no sólo en la hipótesis de probable legítima defensa privilegiada del artículo 138 CPP. En cuanto a los restantes lugares de detención, su condición de "públicos" debe ser considerada en dos sentidos: por una parte, debe saberse cuáles son y dónde están, para así tener conocimiento respecto del paradero del detenido; por otra, quienes visiten al privado de libertad -juez, médico, abogado, familiares, etc.- deben poder acceder a tales recintos ${ }^{187}$.

Observando las reflexiones de la doctrina sobre las características que deben poseer estos lugares, se advierte que la garantía tiene un afán de protección de otros derechos -vida, integridad, etc.-, encontrándose alusiones

${ }^{183}$ Nuestra Constitución emplea el término "formas", que resulta coherente entonces con el dispuesto en el artículo 9.1 PIDCP., "procedimiento". El artículo 7,2 CADH., por su parte, alude a "condiciones" de la detención.

${ }^{184}$ Bovino, A., cit. (n. 66), pp. 32 y 66. Véase la parte del párrafo 47 de la sentencia del caso "Gangaram Panday", transcrita en nota 119.

${ }^{185}$ Cfr. Roxin, C., cit. (n. 60), p. 2. "Los límites a la facultad de intervención del Estado que deben proteger al inocente frente a persecuciones injustas y afectaciones excesivas de la libertad, y que también deben asegurar al culpable la salvaguarda de todos sus derechos de defensa, caracterizan al principio de formalidad del procedimiento. Aunque la sentencia consiga establecer la culpabilidad del acusado, el juicio sólo será adecuado al ordenamiento procesal (principio de formalidad), cuando ninguna garantía formal del procedimiento haya sido lesionada en perjuicio del imputado".

${ }^{186}$ Artículo $19 \mathrm{~N}^{\circ} 7 \mathrm{~d}$ ) inciso 1: "Nadie puede ser arrestado o detenido, sujeto a prisión preventiva o preso, sino en su casa o en lugares públicos destinados a este objeto".

${ }^{187}$ Evans DE LA CuAdRA, E., cit. (n. 75), p. 184. Véase el artículo 94 letras e), f) yh) CPP. 
también a la propia dignidad humana de quien está privado de libertad ${ }^{188}$. De aquí fluye una exigencia cualitativa, que no se satisface sólo por el hecho de que el lugar esté dispuesto en una ley o reglamento y sea público. En este contexto deben considerarse, además, las normas que disponen la segregación entre imputados y condenados, y entre mayores y menores de edad, que se han vinculado al derecho a la integridad personal de los detenidos ${ }^{189}$.

La ley procesal se refiere a estos lugares como el recinto policial o de detención (artículo 131 CPP.), pero no los detalla. Y, realmente, la dispersión a la que se enfrenta el interesado al momento de querer saber cuáles son, resulta preocupante. Tratándose de una detención aún no controlada judicialmente, interesarán las leyes o reglamentos que organicen la actividad de las policías, dado que antes de la comparecencia judicial no se puede conducir al imputado a un establecimiento penitenciario ${ }^{190}$. A este nivel se generan problemas, por ejemplo, para determinar si un vehículo policial puede constituir un lugar de detención y hasta qué punto ${ }^{191}$. Luego, aunque no se diga expresamente, el tribunal competente también es un lugar de detención, al que se arriba precisamente para la realización del derecho a presentarse ante el juez ${ }^{192}$. Los establecimientos penitenciarios sólo admitirán detenidos una vez que, ampliada la detención, se dicte la orden de ingreso respectiva por el juez ${ }^{193}$.

${ }^{188}$ Verdugo Marinkovic, M. - Pfeffer Urquiaga, E. - Nogueira AlcaLÁ, H., cit. (n. 75), I, p. 240; Silva Bascuñán, A., cit. (n. 21), XII, p. 46. Véase el artículo 5.2 CADH.

${ }^{189}$ Medina Quiroga, C., cit. (n. 36), pp. 203 ss. Véanse el artículo 5 CADH., el artículo 37 c) de la Convención sobre derechos del niño y el artículo 31 de la Ley No 20.084. Nuestro Código Procesal Penal sólo dispone la segregación del imputado en prisión preventiva en el artículo 150, pero el artículo 5,3 de la Convención resulta aplicable al detenido y el artículo 14 del Reglamento Penitenciario diferencia los centros de detención preventiva de los centros de cumplimiento penitenciario.

${ }^{190}$ Véanse el artículo 133 CPP. y el artículo 11 del Reglamento Penitenciario. Véase, por ejemplo, el Decreto $\mathrm{N}^{\circ} 91$ de 1982 que aprueba texto del Reglamento de administración de reparticiones y unidades de Carabineros, $\mathrm{N}^{\circ} 3$.

${ }^{191}$ Funcionarios de Carabineros, realizando labores de patrullaje, detienen a un sujeto por delito flagrante haciéndolo abordar el vehículo policial y luego prosiguen su camino, vigilando una población toda la noche. No parece que el detenido deba asumir el riesgo de la labor policíaca por su condición -menos si éste se incrementa con una persecución a otro vehículo, o con un tiroteo- sino, por el contrario, que el traslado inmediato a un recinto seguro es el deber de tales funcionarios.

${ }^{192}$ Véanse los artículos 70 y 72 CPP.

${ }^{193}$ Importan en este punto las normas referidas a segregación, regulándose también casos especiales, que entendemos se vinculan con la integridad del imputado; así, el artículo 15 del Reglamento Orgánico de Policía de Investigaciones de Chile dispone, en lo pertinente: "Los funcionarios de la Policía de Investigaciones de Chile que sean privados de libertad en virtud de resolución judicial, motivada por hechos derivados de actos propios 
b) El tiempo de la detención. La detención deja al imputado en una situación de precariedad, dado que se encuentra bajo el control de sus aprehensores, de quienes depende completamente, tanto en lo que dice relación con la preservación de su vida e integridad, como respecto de la posibilidad de ejercer sus garantías judiciales. De aquí, la brevedad de los plazos y la urgencia de poner al detenido a disposición del juez ${ }^{194}$.

La existencia de plazos se vincula estrechamente con la finalidad que se asigne a la detención. Si se predica que la detención sólo es el modo de conducir forzosamente al imputado a la presencia judicial, tiene pleno sentido sostener que ello debe ocurrir "sin demora" 195 , lo que puede significar algo distinto que "de inmediato", pero siendo cautelosos al momento de admitir razones para la tardanza. Se ha sostenido en el ámbito internacional que la expresión "sin demora", deja un margen para preparar el traslado del imputado ${ }^{196}$. A esto debe añadirse que, si se trata de una detención por delito flagrante, desde la perspectiva constitucional no constituiría pretexto el estarse realizando diligencias de investigación, pues ella opera "con el solo objeto de ser puesto a disposición del juez competente" 197 , lo que resulta problemático, según se dirá. Tratándose de una detención por orden judicial, se prescribe expresamente por la ley la obligación de inmediata conducción del detenido, a menos que no sea hora de despacho [artículos 94 letra c) y 131 inciso $1^{\circ} \mathrm{CPP}$.].

La Constitución establece plazos máximos. De conformidad con el artículo $19 \mathrm{~N}^{\circ} 7$ letra c) inciso $1^{\circ}$, en el caso de la detención por delito flagrante siempre se cuenta con un máximo de 24 horas para poner al detenido ante el juez. El inciso $2^{\circ}$ de la letra indicada, en cambio, es confuso, debido a un desajuste en cuanto a quiénes pueden ordenar la detención. Pendiente una necesaria modificación, aún señala: "Si la autoridad hiciere arrestar o detener a alguna persona, deberá, dentro de las cuarenta y ocho horas siguientes, dar aviso al juez competente, poniendo a su disposición al afectado". Esto, no obstante que tal autoridad es, en el sistema actual, el propio juez. A pesar de su oscuridad, por exclusión, podría considerarse aplicable a los casos de

del servicio, permanecerán detenidos mientras no se decrete su libertad, en los cuarteles de la Institución, que se considerarán habilitados como cárceles para este efecto, hasta la dictación de sentencia definitiva./ A petición del Director General, los funcionarios privados de libertad por resolución judicial, por hechos que no sean propios del servicio, permanecerán detenidos en los mismos recintos".

${ }^{194}$ Salas Astraín, J., cit. (n. 101), p. 381. Durán Fuica, R., cit. (n. 128), p. 193.

${ }^{195}$ Véase el artículo 7.5 CADH.

${ }^{196}$ Medina Quiroga, C., cit. (n. 36), p. 231.

${ }^{197}$ Artículo $19 \mathrm{~N}^{\circ} 7$ letra c) C.Pol.. 
detención por orden judicial ${ }^{198}$, contemplándose un plazo máximo de 48 horas, salvo que el propio juez por resolución fundada disponga que se amplíe hasta por 5 días ${ }^{199}$, o incluso 10 días $^{200}$, tratándose de delitos terroristas ${ }^{201}$; de no entenderse así, la detención por orden judicial carecería de un plazo máximo constitucional. Sabido es que, en todo caso, en virtud del artículo $131 \mathrm{CPP}$. , la regla general en el proceso penal es de un plazo máximo de 24 horas, tanto para la detención por orden judicial como aquella por delito flagrante. El plazo es para que el detenido sea puesto ante el juez y no sólo para permanecer en el lugar de detención. Esto por varias razones. En primer lugar, no parece razonable entender que sacando al detenido del recinto de detención ya no corre plazo para ponerlo a disposición del juez, sobre todo si la exigencia de lugares públicos de detención constituye una garantía para el imputado. Luego, configurar este motivo de excusa puede dar pie para un actuar negligente de la policía, que así se vería fácilmente amparada en ello para justificar tardanzas. En fin, no hay razón para plantear un tratamiento diferenciado en cada uno de los casos de detención, y ya la Constitución, tratándose de detención por delito flagrante, ha señalado que el plazo de 24 horas es para poner al imputado a disposición del juez competente ${ }^{202}$.

c) El modo de ejecutar la detención. El modo en que se lleva a cabo la detención, está ordenado, en primer término, por disposiciones que establecen explícitamente una serie de deberes de los órganos estatales -adicionales a los examinados en cuanto a lugar y tiempo de la detención- y, luego, por disposiciones que expresan una serie de derechos del detenido ${ }^{203}$. De todas ellas se desprende que la detención supondrá un conjunto de actos, algunos de realización necesaria y otros sólo eventuales, que habrán de llevar a cabo principalmente los órganos de persecución y, también, el juez.

Centrándonos en los deberes normados, puede hacerse una enunciación, a título ejemplar: i) la dictación de la orden cumpliendo con los requisitos respectivos, y su intimación; $i i$ ) la necesidad de constancia de la orden en un registro público; iii) el registro del detenido respetando la regulación legal (artículo 89 CPP.); el respeto de la procedencia y formas de la incomunicación (artículo 19 No 7 letra d) C.Pol., y artículos 94 letras f) y h) y 151

\footnotetext{
${ }^{198}$ Cfr. Horvitz, M. I.- López, J., cit. (n. 62), I, p. 384.

${ }^{199}$ Véase el artículo 39 de la Ley No 20.000.

${ }^{200}$ Véase el artículo 11 de la Ley No 18.314.

${ }^{201}$ Véase: Durán Fuica, R., cit. (n. 128), pp. 194-195. Cfr. Silva Bascuñán,
} A., cit. (n. 7), XII, p. 39.

${ }^{202}$ Cfr. Horvitz, M. I. - López, J., cit. (n. 62), I, p. 384.

${ }^{203}$ Que se encuentran tanto en la Constitución, como en los tratados internacionales (artículo 7 CADH. y artículo 9 PIDCP., entre otros) y en el Código Procesal Penal (artículos 93 y 94 , principalmente). 
CPP.]; iv) la información del hecho imputado y los derechos que asisten al sujeto [artículo $7.4 \mathrm{CADH}$. y artículos 93 letra a), 94 letras a) y b), 135 y 136 CPP.]; $v$ ) la información a terceros del hecho de la detención [artículos 94 letra e) CPP.]; vi) el reconocimiento médico (artículo 20 del Decreto-ley № 2.640 de 1979: Orgánico de Policia de Investigaciones); vii) la posibilidad de ingresar a un lugar cerrado en una persecución, según la regulación legal (artículo 129 inciso $5^{\circ} \mathrm{CPP}$.); viii) el aviso al ministerio público por parte de la policía (artículo 131 inciso $2^{\circ} \mathrm{CPP}$.); ix) el aviso a un abogado por parte del fiscal (artículo 131 inciso $3^{\circ} \mathrm{CPP}$.); $x$ ) la conducción y puesta a disposición del detenido ante un juez competente [artículo $19 \mathrm{~N}^{\circ} 7$ letra c) C.Pol., que perfecciona lo dispuesto en el artículo 7.5 CADH.]; xi) la audiencia ante dicho juez competente (artículo 132 CPP., como expresión del derecho consagrado en el artículo 7.6 CADH. $)^{204}$, etcétera. La existencia de estos deberes procedimentales para el Estado, sólo es comprensible como un mecanismo de perfeccionar la garantía de la seguridad individual y, también, de otros derechos fundamentales que pueden verse afectados con ocasión de la privación de libertad. Así, tras cada elemento del rito, se advierte cómo lo buscado es garantizar un derecho específico.

En términos generales, cabe aseverar que el incumplimiento de los deberes impuestos al Estado, así como el impedir el ejercicio de los derechos del imputado detenido, acarrean la ilegalidad de la detención, por incumplimiento de sus formas.

\section{LA DETENCIÓN ILEGAL ORIGINARIA POR DEFECTO EN LOS FINES DEL PROCEDIMIENTO}

Doctrinariamente, se han señalado como fines del procedimiento, que hacen admisible la aplicación de medidas cautelares personales, la correcta averiguación de la verdad y la actuación de la ley penal. También se ha teorizado respecto de la admisión de la prevención inmediata del hecho objeto del proceso ${ }^{205}$. El artículo $19 \mathrm{~N}^{\circ} 7$ C.Pol. establece, con un lenguaje propio, las finalidades que deben estar presentes al momento de imponer tales privaciones de derechos que afecten la persona del imputado. La regulación general se encuentra en la letra e), inciso 1, de la disposición, que en lo pertinente indica: "La libertad del imputado procederá a menos que la detención o prisión preventiva sea considerada por el juez como necesaria para

\footnotetext{
${ }^{204}$ Se ha estimado que los derechos consagrados en los números 5 y 6 del artículo 7 CADH. están íntimamente relacionados. El derecho a ser llevado ante un juez persigue que se verifique el control de la legalidad de la detención; al respecto: Medina QuiroGA, C., cit. (n. 36), p. 230; Bovino, A., cit. (n. 66), p. 26.

${ }^{205}$ MAIER, J., cit. (n. 59), I, pp. 514-515.
} 
las investigaciones o para la seguridad del ofendido o de la sociedad"206. De aquí se extraen tres fines del procedimiento aplicables a la detención ${ }^{207}$. Más que criticarlos, interesa considerar que la Constitución dispone que, alguno de ellos, debe estar presente y vincularse con la medida que se decreta. Ahora bien, de la insuficiente adecuación del texto que comentamos a la reforma procesal penal, ha resultado que el abanico de fines indicado solamente puede ser tenido en cuenta si se trata de ordenar judicialmente la detención, o de estimar su ampliación, expresándolo así fundadamente la resolución respectiva, de conformidad con el artículo 36 CPP. En cambio, el mismo artículo 19 No 7, en su letra c), expresa: "Sin embargo, podrá ser detenido el que fuere sorprendido en delito flagrante, con el solo objeto de ser puesto a disposición del juez competente dentro de las veinticuatro horas siguientes". Esto significa que, tratándose de este caso, lo que se persigue con la detención es únicamente poner al imputado a disposición del juez, obtener su comparecencia, facilitar la actuación de la ley penal. La disposición constituye, entonces, una concreción pura del derecho a ser puesto ante el juez, en concordancia con las normas de los tratados internacionales ${ }^{208}$, cosa que no deja de ser perturbadora, ya que de ello resulta que no existiría fundamento para sostener que el imputado puede ser involucrado en diligencias de investigación durante ese período -las que, dependiendo de su resultado, pueden incluso favorecerle- ${ }^{209}$, ni retardada su puesta a disposición judicial por tal razón, con el consiguiente cuestionamiento de las disposiciones legales que lo permiten, expresa o tácitamente ${ }^{210}$.

${ }^{206}$ Cfr. Duce Julio, M. - Riego Ramírez, C., cit. (n. 112), pp. 258-265. Para salvar los reparos que se hacían al peligro para la seguridad de la sociedad, se propuso entender éste como peligro de fuga. El problema, desde el punto de vista de una política criminal enfocada en la seguridad ciudadana, es que tal identificación hace procedente en forma amplia la caución respecto del privado de libertad (artículo 146 CPP.). La ley 20.253 reformó los artículos 140 c) y 155 CPP., mencionando por separado ambos motivos de necesidad de cautela. Cabe preguntarse si ambas disposiciones son constitucionales, ya que consagran como cuarto fin del procedimiento el peligro de fuga, no contenido en el artículo $19 \mathrm{~N}^{\circ} 7$ letra e) C.Pol.

${ }^{207}$ Sobre su alcance y relación con las categorías doctrinales, véanse: HoRvitz, M. I. - López, J., cit. (n. 62), I, pp. 82 ss.; Duce Julio, M. - Riego Ramírez, C., cit. (n. 112), pp. 254 ss.

${ }^{208}$ Véanse los artículos 7.5 CADH. y 9.3 PIDCP.

${ }^{209}$ Cfr. Duce Julio, Mauricio - Riego Ramírez, C., cit. (n. 112), p. 163. Por otra parte, la persecución penal no se inhibe o suspende por el hecho de que el imputado esté privado de libertad.

${ }^{210}$ Así el artículo 193 inciso 2 CPP., que regula la comparecencia del imputado ante el ministerio público: "Mientras el imputado se encuentre detenido o en prisión preventiva, el fiscal estará facultado para hacerlo traer a su presencia cuantas veces fuere necesario para los fines de la investigación, sin más trámite que dar aviso al juez y al defensor". Tam- 
En cuanto a las posibles situaciones de ilegalidad de la detención por ausencia de finalidad, téngase como ejemplo el del imputado que, enterándose que tiene una orden de detención por incomparecencia, se dirige a presentarse al tribunal que la ha dispuesto. Si la policía practica la detención antes que éste logre ingresar, no existe un fin del procedimiento que la justifique ${ }^{211}$.

\section{LA DETENCIÓN ILEGAL DERIVADA}

Existen al menos dos maneras de justificar esta clase de detención ilegal, para que sea considerada a la par de la que hemos denominado originaria.

La primera, razonando desde la perspectiva de los casos en que es posible detener. Los ejecutores de la medida cautelar, ya sea en virtud de una orden judicial o de delito flagrante, deben encontrarse en la posibilidad material de llevarla a cabo, pero también es indispensable que se encuentren posibilitados jurídicamente para ello. De lo contrario, la burla a la normativa por parte de quienes la practican resulta fácil. Si un policía elige a un ciudadano al azar y realiza el procedimiento de control de identidad, sin encontrarse en uno de los casos fundados dispuestos por el artículo 85 CPP., y en el registro le descubre droga, deteniéndolo, lo cierto es que el policía ha infringido la ley y en definitiva, a pesar del resultado, ha pasado por sobre el Estado Constitucional de Derecho. El policía nunca debió, jurídicamente, poder apreciar dicho delito flagrante. Si un policía golpea a un ciudadano para que se identifique y, gracias a que dio su nombre, se descubre que existía una orden de detención a su respecto, ejecutándola, sucede lo mismo que en el caso anterior ${ }^{212}$. El deber de realizar sólo aquello que está jurídicamente permitido, se desprende del ya mencionado artículo 6 C.Pol.

La segunda manera de explicar la existencia de la detención ilegal derivada, es mediante su vinculación con el cumplimiento de las formas respectivas. Esto porque la policía debe acatar el procedimiento establecido jurídicamente y éste, de acuerdo con cierta doctrina y jurisprudencia, no sólo consiste en el dispuesto en aquellas normas que se refieren propia o directamente a la detención, sino también en el señalado en cualquier otra norma que deba ser tomada en cuenta para un cumplido ejercicio al materializar la cautelar ${ }^{213}$.

bién el artículo 151, a propósito de la incomunicación, en lo pertinente: "El tribunal podrá, a petición del fiscal, restringir o prohibir las comunicaciones del detenido o preso hasta por un máximo de diez dias, cuando considerare que ello resulta necesario para el desarrollo de la investigación".

${ }^{211}$ Véanse el artículo 126 CPP. y el artículo 318 bis CdPP.

${ }^{212}$ Cfr. Piedrabuena Richard, G., cit. (n. 102), p. 91.

${ }^{213}$ Bovino, A., cit. (n. 66), p. 67. "Es indispensable señalar que la Corte Interamericana, tanto en 'Gangaram Panday' como en 'Suárez Rosero', no estableció distinción 
Es decir, el sentido del término constitucional "formas", que hemos considerado equiparable a "procedimiento", según esta posición debe estimarse en un sentido amplio.

Cualquiera sea el fundamento tomado en cuenta, se aprecia que en estas situaciones, al controlarse la detención, habrá también de llevarse a cabo un examen de legalidad de los actos previos a aquélla, que condujeron a los aprehensores a realizarla, para determinar si tales actos generaron la posibilidad jurídica de la detención, o sólo la permitieron en un sentido material. Este es el escenario común, que puede desembocar en una declaración de ilegalidad de la detención.

Pero cabe hacer presente que, cosa distinta sucede cuando, durante el desarrollo de una actividad de persecución, que puede ser ilegal, el imputado comete un delito flagrante, enteramente nuevo. En esta hipótesis, se interrumpe la continuidad del actuar ilícito de los órganos de persecución, por un hecho punible del propio imputado. En consecuencia, se actualiza la posibilidad de obrar privando de libertad. Por ejemplo, si se está controlando sin motivo la identidad a una persona y, durante el registro, ésta aprovecha un descuido, quita el arma al policía y le dispara, matándolo. No cabe sostener la ilegalidad de la detención por el homicidio flagrante.

Los actos contrarios al ordenamiento jurídico que sirven de base para sostener la ilegalidad de la detención son múltiples. Para efectos expositivos, los separaremos en cuatro grupos:

\section{Actos realizadospor los órganos de persecución, en el contexto de un proceso} penal ya iniciado ${ }^{214}$.

De éstos, el que parece estar más comúnmente unido a situaciones de detención ilegal es el control de identidad, con sus propias causales y proce-

alguna entre los diferentes 'procedimientos' a los que debe observarse 'estricta sujeción'. Por el contrario, requiere 'estricta sujeción a los procedimientos...' establecidos en las normas internas, esto es, a todos ellos. Por lo tanto, los aspectos formales no se verían cumplidos si, por ejemplo, la detención, aún con orden judicial, fuera llevada a cabo como consecuencia de la obtención de pruebas ilícitas". Cfr. Nogueira Alcalá, H., cit. (n. 62), II, p. 418. Exponiendo el principio de reserva legal, cita la sentencia del caso "Ivon Neptune vs. Haití", de 6 de mayo de 2008. En su párrafo 96, a propósito del alcance del artículo 7.2 CADH., ésta indica: "Por ello, cualquier requisito establecido en la ley nacional que no sea cumplido al privar a una persona de su libertad, hará que esa privación sea ilegal y contraria a la Convención Americana”. Cfr. Evans de LA CuADRA, Enrique, cit. (n. 75), pp. 179-180. Sobre un enfoque, pertinente, respecto de la deseable amplitud de la tutela judicial frente a la actividad administrativa, AldunAte Lizana, E., Derechos, cit. (n. 2), pp. 193-194.

${ }^{214}$ Cfr. Horvitz, M. I. - López, J., cit. (n. 62), I, pp. 471-472. 
dimiento para llevarlo a cabo, dispuestos en el artículo 85 CPP. ${ }^{215}$. En esta categoría se incluyen, luego, las diligencias intrusivas ${ }^{216}$, tanto las que poseen nombre y regulación legal -entrada y registro en lugar cerrado, interceptación de telecomunicaciones, etc.-, como las que siendo innominadas, puedan afectar derechos del imputado o, incluso, de un tercero, de conformidad con los artículos 83 inciso $3^{\circ} \mathrm{C}$.Pol. y 9 inciso $2^{\circ} \mathrm{CPP}$. También las propias detenciones ilegales, cualquiera sea la causa que las motive y que conduzcan a materializar, en el contexto de su ejecución, registros o diligencias que lleven a advertir un delito flagrante ${ }^{217} \mathrm{u}$ órdenes de detención pendientes, o permitan la obtención de antecedentes para solicitar una orden de detención ${ }^{218}$. Habrá actividad de persecución que permita extraer más hipótesis, por ejemplo, coaccionar a un imputado para que declare inculpando a otro, y así obtener la orden de detención del segundo; realizar falsas promesas de ventajas procesales a un imputado (artículo 195 inciso $1^{\circ} \mathrm{CPP}$.) para que declare dónde se encuentran los medios de prueba del hecho que se le atribuye, y fundar con ello la solicitud de orden de su propia detención, etc.

\section{Actos realizados por funcionarios públicos.}

Dependiendo del ámbito de competencia, pueden ser de lo más variados. Pensamos especialmente en situaciones en que la ley permite a determinados funcionarios una afectación de derechos de particulares, para verificar el cumplimiento de normas que regulan sectores de actividad -fiscalizaciones-, o asegurar el normal desenvolvimiento de éstos. Ellas sólo proceden ateniéndose a los casos y formas previstos. Por ejemplo, corresponde a la autoridad sanitaria controlar el funcionamiento de los locales destinados a la venta de alimentos, y para ello puede practicar la inspección y registro de

${ }^{215}$ A nuestro parecer, correctamente, resolución de la Corte de Apelaciones de Antofagasta, de 20 de diciembre de 2007, rol N²79-2007. Confirma resolución que declaró ilegal la detención de quien acudió a una unidad policial, a pedir el teléfono para solicitar una grúa por desperfectos en su vehículo, y fue sometido a control de identidad con registro, fundado sólo en la experticia policial, encontrándosele una pistola en su mochila. Hay voto disidente.

${ }^{216}$ Véase resolución de la Corte de Apelaciones de Valparaíso, de 13 de diciembre de 2004, rol N ${ }^{\circ}$ 633-2004.

${ }^{217}$ Por ejemplo, suena la alarma de robo de una bodega y la policía detiene a un sujeto que simplemente deambulaba por las cercanías. No hay aquí hipótesis de flagrancia $\mathrm{y}$, en consecuencia, la detención es ilegal. Al registrar al detenido, se le descubre una bolsa de marihuana. No cabe sustentar la legalidad de su detención, ahora, en el delito de porte de estupefacientes.

${ }^{218}$ En este sentido, resolución del Juzgado de Garantía de Paillaco, de 24 de junio de 2004, RUC 0400224216-3. 
dichos lugares ${ }^{219}$. Pero, si se trata de lugares cerrados, se debe actuar previo decreto del funcionario competente para autorizarlo. Luego, si se practica este acto omitiéndose el decreto que lo autoriza, y se descubre una casa de juego (artículo 277 CPP.), procediendo la fuerza pública a privar de libertad a su administrador, se aprecia también una hipótesis de detención ilegal ${ }^{220}$.

\section{Actos de particulares.}

Cabe plantearse si, acaso, es legal la detención que sólo ha resultado posible gracias al acto de un particular, que es contrario a derecho. Por ejemplo, la policía pierde el rastro de un delincuente flagrante, y expira todo tiempo inmediato posible que mantenga el estado in fraganti, de acuerdo con la ley [artículo 130 letra e) CPP.]. Pero alguien que sabe donde vive, ingresa violentamente a su morada, lo captura y toma los efectos del delito que pueden servir de medio de prueba. Presentado en una comisaría, se opta por recabar una orden de detención, fundada en tales elementos, y así detenerlo. Esto nos remite a la problemática general de las consecuencias de los actos de particulares en el proceso penal, cuando afecten indebidamente derechos fundamentales, lo que amerita un estudio aparte $\mathrm{e}^{221}$.

\section{Denuncias anónimas.}

Esta situación podría incluirse dentro de los actos de particulares, o bien, dentro de los actos de los órganos de persecución. Ello ya revela parte de su

${ }^{219}$ Véanse los artículos 110 y 155 a 160 del Código Sanitario.

${ }^{220}$ Otro ejemplo: el artículo 27 de la Ley No 19.925 , permite la conducción a un cuartel policial de quien sea sorprendido consumiendo bebidas alcohólicas en lugares públicos, para los fines que indica. Pero no se faculta al registro de las vestimentas o equipaje del infractor, por lo que de llevarse a cabo, constituye un acto ilegal, que no posibilita jurídicamente una detención por delito flagrante. La resolución de la Corte de Apelaciones de Antofagasta, de 31 de diciembre de 2008, rol N³10-311, al revocar una resolución que declaró ilegal la detención efectuada en el contexto de un control vehicular regulado por la Ley No 18.290 , expone: "Si esta detención se produjo como consecuencia del hallazgo de gran cantidad de droga, se justifica en virtud del artículo 130 letra a) del Código Procesal Penal en la medida que los imputados estaban cometiendo el delito contemplado en la Ley 20.000 al transportar esta droga, no discutida por los intervinientes; por lo tanto la detención no ha podido ser ilegal si ella se justifica en una norma legal y hechos concretos; distinto sería el cuestionamiento del allanamiento o inspección del vehículo, circunstancias que no se han cuestionado en la audiencia $[\ldots]$ ".

${ }^{221}$ El tema se proyecta al ámbito de la detención, las otras medidas cautelares y las diligencias intrusivas, así como al de la prueba ilícita. Al menos en este último, se ha resuelto que existe prueba ilícita cuando su obtención ha sido por un particular, que ha actuado con inobservancia de garantías fundamentales. Véase sentencia de la Corte Suprema, de 11 de junio de 2007, rol N¹836-07. 
problemática: frente a la denuncia anónima cabe oponer la duda legítima de si acaso ella existió realmente. De conformidad con el artículo $174 \mathrm{CPP}$. , en toda denuncia criminal el denunciante debe identificarse y, si es verbal, debe estar presente y suscribirla. Esto no es un simple capricho; las delaciones se prestan para usar al sistema penal como herramienta de venganza entre particulares, impidiendo la ulterior persecución del delator por denuncia calumniosa ${ }^{222}$; sirven para disimular actividad de persecución no permitida por el derecho $0^{223} \mathrm{y}$ disminuyen la capacidad de defensa del imputado, entre otras $\operatorname{cosas}^{224}$. Por eso, regularmente en las leyes de procedimiento sólo se aceptan con efecto limitado 225 .

Desde nuestro punto de vista, para saber qué mérito otorgar a una denuncia anónima, hay que distinguir dos planos. Si ella describe un hecho punible, su toma de conocimiento por parte de los órganos de persecución penal debe considerarse bastante para iniciar una investigación pues, desde la perspectiva de aquéllos, sin importar cómo se adquiera la información, legalmente habrán de proceder de oficio (artículos 166 y 172 CPP.). En cambio, una denuncia anónima no debiera ser tomada en cuenta como fundamento de actos de persecución o jurisdiccionales, que puedan afectar derechos fundamentales; es decir, a ella no puede conferirse la virtud de operar como antecedente en la solicitud de una orden de detención, de prisión preventiva u otras medidas cautelares, ni en la solicitud de autorización de diligencias intrusivas. Tampoco, como elemento que pueda usarse para argumentar la existencia de una hipótesis de flagrancia ni un caso fundado de control de identidad ${ }^{226}$. Sin embargo, como un argumento central para sostener la inadmisibilidad de denuncias anónimas, en este orden de cosas, es el impedir que ellas sean usadas como pretexto para realizar actividad de

${ }^{222}$ Véase el artículo 178 CPP.

${ }^{223}$ Para un caso expresivo, véase resolución de la Corte de Apelaciones de Concepción, de 18 de octubre de 2008, rol N³96-2008.

${ }^{224} \mathrm{Cfr}$. Binder, A., Introducción al derecho procesal penal (2a edición, Buenos Aires, Ad-Hoc, 1999), p. 234.

${ }^{225}$ El artículo 92 del Código de Procedimiento Penal dispone: "Los tribunales no darán curso a denuncias hechas por personas desconocidas ni a delaciones, a no ser que contengan datos precisos que hagan verosimil que se ha cometido el hecho denunciado o delatado. En tal caso procederá el juez, previamente, a verificar los datos con el mayor secreto, procurando no comprometer la reputación de la persona inculpada". Consúltense también, por ejemplo, los artículos 333, 3 y 240 del Código de Procedimiento Penal italiano, el artículo 328 del Código Procesal Penal peruano y el artículo 268 de la Ley de Enjuiciamiento Criminal española. Cfr. Roxın, C, cit. (n. 60), p. 328.

${ }^{226}$ En un sentido aproximado, resolución del $4^{\circ}$ Juzgado de Garantía de Santiago, de 10 de marzo de 2006, en causa RUC 0600170080-2, revocada por la Corte de Apelaciones de Santiago, por resolución de 9 de mayo de 2006. 
persecución ilegal, consideramos que, al menos en materia de control de identidad y estimación de flagrancia, ello pueda ser matizado tratándose de situaciones en que, al momento de controlarse la detención, se compruebe que la persona que realizó la denuncia realmente existía y sus dichos eran efectivos $^{227}$.

\section{EL JUICIO ACERCA DE LA LEGALIDAD DE LA DETENCIÓN}

\section{Características del juicio de legalidad de la detención.}

De nada serviría el momento jurisdiccional de la audiencia de control de la detención, si la evaluación acerca de su legalidad estuviese entregada al sujeto aprehensor. Corresponde al juez determinar la legalidad de la detención. En materia de medidas cautelares en general, el principio de jurisdiccionalidad implica que ellas deben adoptarse por resolución judicial fundada ${ }^{228}$, previo debate de los intervinientes ${ }^{229}$. Tratándose de la detención, el control previo sólo puede efectuarse cuando aquélla opera por orden judicial pero, normalmente, en este caso no existirá la posibilidad de un debate anterior a la resolución que se pronuncia sobre su solicitud ni, en un número considerable de solicitudes, el juez podrá apreciar directamente los antecedentes que servirán de base a su pronunciamiento - piénsese en las órdenes solicitadas telefónicamente, por ejemplo-. Además, ya sea que se trate de un caso de delito flagrante o de llevar a efecto una orden judicial, será necesario verificar que se ha cumplido a cabalidad con el procedimiento de detención ${ }^{230}$. Por lo tanto, en materia de detención lo propio es que el control judicial se realice a posteriori.

Consecuencia de lo anterior es que toda detención sea controlable; no importa el caso en que nos encontremos -delito flagrante u orden judicial-, siempre la procedencia de la cautelar debe ser susceptible de examen por un juez ${ }^{231}$. El artículo 7 CADH., en sus números 5 y 6 , no hace distinción al respecto.

${ }^{227}$ Véase resolución de la Corte de Apelaciones de Antofagasta, de 7 de febrero de 2008, en causa RUC 0800085028-5.

${ }^{228}$ Marín González, J. C., cit. (n. 76), p. 20; Horvitz, M. I. - López, J., cit. (n. 62), I, p. 350.

${ }^{229}$ Véanse los artículos 142 y 155 inciso final CPP.; Maturana Miluel, C. Montero López, R., cit. (n. 78), p. 453. Chahuán Sarrás, Sabas, cit. (n. 92), p. 203.

${ }^{230}$ Arias Vicencio, C., cit. (n. 62), p. 237. Señala: “[...] el examen de legalidad no se puede agotar en el análisis del origen de la detención, sino que también es preciso poner atención a su ejecución".

${ }^{231}$ Véase: Durán Fuica, R., cit. (n. 128), p. 194; Arias Vicencio, C., cit. (n. 62), pp. 232 y 244-246; Piedrabuena Richard, G., cit. (n. 102), p. 121; Medina Jara, 
El control judicial a posteriori, por regla general, debe realizarse desde una perspectiva ex - ante ${ }^{232}$. Es decir, colocándose el juez en la posición de un observador imparcial al momento de la detención, tomando en consideración todos los conocimientos de hecho que tenía el agente al obrar, y todos los que le habrían sido razonablemente exigibles ${ }^{233}$.

De lo anterior fluye, en primer lugar, que no cabe validar una detención por antecedentes conocidos después de practicada ella. Por ejemplo, Carabineros durante un patrullaje nocturno ve a dos sujetos corriendo y guardando especies entre sus ropas y éstos, al ser perseguidos, las arrojan al suelo. Son detenidos y, luego, llegan las víctimas al lugar y reconocen los objetos como de su propiedad y a los imputados como autores de un robo por sorpresa. La detención es ilegal ${ }^{234}$.

En segundo lugar, se concluye que el error de hecho en que incurre quien realiza una detención, no es motivo para considerar ésta como ilegal. Por ejemplo, si se sorprende a una persona forzando la cerradura de un automóvil y es detenida por tentativa de robo, la detención es legal, aunque luego se compruebe que en realidad se trataba del dueño que había extraviado las llaves. Lo mismo, si la víctima de un delito se confunde y, en vez de señalar

R. - Morales Palacios, Luis - Dorn Garrido, Carlos, Manual de derecho procesal penal (2a edición, LexisNexis, Santiago, 2007), p. 290; Duce Julio, M. - Riego RAmírez, C., cit. (n. 112), p. 273; Bovino, A., cit. (n. 66), p. 29. Cfr. Salas Astraín, J., cit. (n. 101), p. 383. Horvitz, M. I. - López, J., cit. (n. 62), I, p. 376; Cerda SAN MARTín, R., Manual del sistema de justicia penal (2a edición, Librotecnia, Santiago, 2010), I, p. 356. Evidentemente surgen ciertos problemas como lo impropio que resultaría declarar ilegal la detención producto de una orden judicial, por el mismo juez que la impartió; o, si la orden fue dictada por otro juez, en caso que el que la controle estime que los antecedentes que la fundaron eran insuficientes. Sin embargo, pensamos que el asunto no puede zanjarse proponiendo que la detención por orden judicial no sea controlable, tanto porque al dictarse la orden no se sabe si el procedimiento habrá de adoptarse conforme a la ley, como porque sí parece adecuado que haya una posibilidad de verificar que los antecedentes proporcionados eran existentes, íntegros y veraces.

${ }^{232} \mathrm{Hemos}$ señalado antes un caso excepcional que nos parece aceptable, a propósito de las denuncias anónimas.

${ }^{233}$ Cfr. Cisterna Pino, A., cit. (n. 101), pp. 59-60.

${ }^{234}$ Resolución del Juzgado de Garantía de Coquimbo, de 1 de noviembre de 2001, RUC 0100064737-K. La actividad policial se facilita, en este sentido, por la vía del control de identidad; pero sin descuidar que, en esta institución, cabe aplicar el mismo principio para la apreciación del caso fundado. RABi GonZÁLEZ, Roberto, Roly justificación del control de identidad a la luz del actual texto del artículo 85 del Código Procesal Penal, en Revista de Derecho de la Universidad Católica de la Santísima Concepción, 18 (2008), p. 56. 
a la policía a quien realmente lo cometió, sindica a otro que, en definitiva, nada tuvo que ver con el hecho ${ }^{235}$.

Cosa distinta ocurre con el error de derecho. Los órganos del Estado -en este caso, los de persecución penal que actúan la detención-, para poder cumplir con el deber de sometimiento a la Constitución y las normas dictadas conforme a ella, primero deben conocerlas. Ello es siempre exigible, puesto que es el mismo Estado quien, por una parte, crea las normas y, por otra, dispone cuáles serán las personas a su juicio idóneas que habrán de ejecutarlas. De lo contrario, los defectos jurídicos en la realización del acto de privación de libertad y el procedimiento que le sigue, quedarían íntegramente de cargo del imputado y se conformaría un Estado irresponsable. Además, no debe olvidarse que, en esta materia, corresponde también aplicar el artículo $8 \mathrm{CC}$. El punto resulta de particular interés en aquellas situaciones en que el hecho punible se corresponde con la aparente realización de un tipo penal que está compuesto por elementos normativos y que, por lo mismo, no constituyen aspectos de hecho ${ }^{236}$. Otro aspecto relevante, que concierne a lo tratado aquí, es el de la calificación jurídica de los hechos por los que se detiene. Si al momento de la detención la policía asigna una determinada calificación jurídica, que la ha hecho posible, y ella es desestimada posteriormente por el juez que controla la detención, estaremos frente a un error de derecho que se traduce en ilegalidad ${ }^{237}$. Se expresa así el principio "iura novit curia" en

${ }^{235}$ Pero el estándar referido para situarse en la perspectiva ex ante debe ser tomado en cuenta. Si un policía advierte que un sujeto lleva consigo una sustancia en polvo, y lo detiene por el delito de porte de estupefacientes, resultando que se trataba de talco, la detención es ilegal, pues dicho funcionario debe contar con habilidades que le permitan distinguir con cierta precisión.

${ }^{236}$ Por ejemplo, el artículo 168 inciso 2 de la Ordenanza de Aduanas, dispone: "Incurrirá en el delito de contrabando el que introduzca al territorio nacional, o extraiga de él, mercancías cuya importación o exportación, respectivamente, se encuentren probibidas". Si se lleva a cabo una detención por delito flagrante de contrabando, no obstante que la mercancía no haya sido de importación o exportación prohibida, tal detención es ilegal. Para estos efectos no interesa si la privación de libertad fue intencionalmente efectuada en un caso no permitido, o si se debió a un error de derecho. Véase el artículo 178 de la misma Ordenanza, que establece pena privativa de libertad a partir de cierto valor de la mercancía.

${ }^{237} \mathrm{Si}$ un hombre de cincuenta años es sorprendido accediendo carnalmente a una joven de dieciséis, y es detenido por estupro, sin que la policía haya apreciado la concurrencia de alguna de las circunstancias que vician el consentimiento de la víctima, del artículo 363 CP., la detención es ilegal. Si tres sujetos caminan juntos y dos de ellos abordan a una persona, intimidándola y sustrayéndole objetos, mientras el tercero queda atrás, sin hacer nada, y los tres son detenidos como coautores de robo con intimidación, la detención del simple observador es ilegal, si se le privó de libertad sin haber sido ostensible un concierto previo (artículo $15 \mathrm{~N}^{\circ} 3 \mathrm{CP}$.). Resulta tentador el admitir 
materia de control de la detención. Las situaciones de errónea calificación jurídica constituyen hipótesis de ilegalidad de la detención, fundadas en que el hecho no es constitutivo de delito o, al menos, no es de aquellos por los que la ley ordena o faculta la detención o, en que la intervención de una persona no puede encuadrarse en alguna figura por la que pueda hacérsele responsable criminalmente ni aún de modo provisional (según los artículos 14 y siguientes CPP. $)^{238}$. En aquellas situaciones en que la calificación jurídica sea dudosa, de modo que el hecho pueda estimarse ya sea como uno por el que procede la detención o, por el contrario, como uno en que ésta no es admisible, la interpretación debe atender a la regla dada por el artículo 5 inciso $2^{\circ} \mathrm{CPP}$., esto es, realizarse en forma restrictiva. En conclusión, si el juez es de la opinión que, en el caso particular, se ha errado en la calificación jurídica de los hechos y, a raíz de ello, se ha practicado una detención que en realidad no era posible, es soberano para resolver declarando la ilegalidad correspondiente.

\section{Prueba de la legalidad de la detención.}

Nos referimos aquí a la situación en que se encuentra el juez que consulta sobre las circunstancias en que se ha producido la detención y que escucha un relato fáctico proveniente del fiscal, que es contradicho por el imputado ${ }^{239}$. Por ejemplo, si el fiscal señala que el parte policial consigna que el imputado,

que los antecedentes que completan la configuración típica puedan sean indagados con posterioridad, pero lo cierto es que, en casos como los que se grafican, se ha actuado deteniendo sin contar con los elementos, legalmente establecidos, para calificar el comportamiento como un auténtico hecho punible, o al sujeto como una persona a quien puede atribuirse participación en él. La ilegalidad fluye, en los ejemplos dados, de la infracción al artículo 130 CPP.

${ }^{238}$ La ley articula mecanismos que dificultan la comprensión de estas ideas. Un individuo es sorprendido portando dos cigarrillos de marihuana. La policía asigna al hecho la calificación jurídica de microtráfico (artículo 4 de la Ley No 20.000) y lo detiene, amparada en que, de acuerdo a la norma, éste no pudo justificar que la sustancia está destinada a su uso o consumo personal exclusivo y próximo en el tiempo -porque, supongamos, decidió mantenerse en silencio-. Subyace aquí una presunción legal de tráfico en pequeñas cantidades, que desplaza la carga de la prueba al imputado quien, si se hubiese estimado simplemente un portador - un consumidor, no podría haber sido detenido (artículo 50 inciso 3 de la Ley No 20.000, relacionado con el artículo 124 CPP.). Ya que la presunción de inocencia está consagrada en tratados internacionales de derechos humanos, cabe preguntarse si es constitucional la disposición del ejemplo.

${ }^{239}$ A diferencia del problema que comenzamos a examinar, muchas veces, el debate acerca de la legalidad de la detención parte de la base de la exactitud del relato hecho por el fiscal. En estas situaciones, la defensa se limita a señalar que, precisamente de acuerdo con aquél, no se han verificado los casos o formas exigidos por el ordenamiento jurídico, o existe una ilegalidad anterior de la que deriva la materialización de la detención. 
fue sorprendido intentando forzar la cerradura de la puerta de un establecimiento comercial y, en cambio, el imputado expresa que fue detenido cerca del lugar, mientras caminaba. O bien, si existe una diferencia en cuanto a la hora de la detención, que incide en el cumplimiento del plazo legal para poner al sujeto disposición del tribunal. Lo mismo si el imputado, consultado acerca de la información de sus derechos, señala que no le fueron comunicados y el fiscal sostiene lo contrario. Existiendo controversia, cabe plantearse a quién corresponde probar los hechos que alega, ya como sustento de una detención legal, ya como constitutivos de una infracción al régimen jurídico de la detención y, por ello, motivo de ilegalidad ${ }^{240}$.

Desde la perspectiva del derecho a un tribunal imparcial ${ }^{241}$, lo propio es que el juez atienda a las versiones de los intervinientes de un modo igualitario. Con esto se quiere expresar la idea de que no corresponde al tribunal conceder, a priori, mayor credibilidad a alguno de ellos. En concreto, las alegaciones fácticas -la expresión de las llamadas "circunstancias de la detención"-, por sí solas, no tienen mayor peso por la sola razón de haber sido formuladas por el fiscal ${ }^{242}$. Esto nos conduce a la necesidad de establecer una regla probatoria en la materia. Opinamos que la regla consiste en que corresponde al Estado - esto es, al ministerio público- acreditar que se han observado las prescripciones del ordenamiento jurídico al efectuar una detención, en caso que el imputado contradiga la versión del fiscal.

Esta perspectiva arranca de la posición, abiertamente desventajosa, en que se encuentra el imputado detenido a quien, si se le impusiera la carga de probar la efectividad de sus dichos, que fundan la detención ilegal, se le estaría encomendando una tarea generalmente imposible de realizar. Por ejemplo, el detenido alega haber sido indebidamente incomunicado y, pese a haber solicitado la presencia de un abogado y, en fin, de un juez de garantía, haber sido ignorado ${ }^{243}$. Simplemente, estas alegaciones no pueden ser probadas por él, con lo que la articulación del sistema de garantías de la libertad personal

${ }^{240}$ Más allá de que en la audiencia se consideren otros aspectos que inciden en su desarrollo, provocando que muchos casos de divergencia en cuanto a los hechos se solucionen por vías que evitan una decisión sobre este punto. Por ejemplo, a través de la recomendación al imputado de ejercer su derecho a guardar silencio o, el disponer la remisión de un oficio a la policía en cumplimiento del artículo 136 CPP.

${ }^{241}$ Artículo 8.1 CADH. y artículo 1 CPP.

${ }^{242}$ Complementa esta idea la existencia del derecho de defensa, pues de poco serviría el poder "ser oído" si no se atiende a sus dichos en un plano de igualdad (artículo 8.1 CADH. y artículo 8 inciso 2 CPP.). También el derecho a la presunción de inocencia, ya que debe descartarse cualquier menoscabo en la credibilidad del imputado fundado en que se le esté atribuyendo participación en un hecho punible, por los órganos de persecución, antes de la sentencia firme de condena.

${ }^{243}$ Artículos $19 \mathrm{~N}^{\circ} 7$ letra d) C.Pol., 93 letra b), 95 y 151 CPP. 
en materia de detención deviene ineficaz ${ }^{244}$. A la desventaja física referida, proveniente de que el imputado está bajo el control de sus aprehensores, se suma como argumento el hecho de que, quien está en condiciones de procurarse en forma anticipada, de mecanismos que le permitan resguardarse de cuestionamientos en su actuar, y puede destinar los recursos para ello, es el Estado. Jurídicamente, este último aspecto constituye una forma de dar cabal cumplimiento al mandato de artículo 5 inciso $2^{\circ} \mathrm{C}$.Pol., en lo que se refiere a la obligación, positiva, de promoción de los derechos fundamentales de las personas en esta materia ${ }^{245}$.

El planteamiento sostenido se ve refrendado por la posición manifestada por organismos internacionales, en el plano de su competencia, pero referida a normas que se proyectan en nuestro ámbito interno ${ }^{246}$. A ello se suma la opinión de cierta doctrina ${ }^{247}$. De aquí se desprende claramente una carga de acreditar la legalidad de la detención y, desde otro ángulo, una presunción a favor del detenido, una vez puesto a disposición del juez competente. Como no existen restricciones al respecto, el ministerio público y, en su caso, la policía, pueden valerse de cualquier medio para acreditar su versión, cosa que regularmente ocurre al exponerse documentos suscritos por determinadas personas - partes policiales, actas de información de derechos, etc.-. El juez, al resolver, expondrá el grado de convicción que le produzcan. Queda un

${ }^{244} \mathrm{La}$ apreciación de situaciones de desequilibrio, han motivado la formulación del principio “favor debilis". Cfr. Nogueira Alcalá, H., cit. (n. 2), I, p. 233.

${ }^{245}$ Cea Egaña, J. L., cit. (n. 12), I, p. 216. Silva BASCuñán, Alejandro, cit. (n. 21), IV, p. 110. El mismo sentido de actividad atribuido al vocablo "promover" -que pretende superar la mera obligación estatal de abstenerse, que se desprende de la expresión respetar-, se asigna al término "garantizar", dispuesto en el artículo $1 \mathrm{CADH}$. Véase: Medina Quiroga, C., cit. (n. 36), p. 16; Nogueira Alcalá, H., cit. (n. 2), I, p. 57.

${ }^{246}$ Corte Interamericana de Derechos Humanos, sentencia del caso "Gangaram Panday vs. Surinam”, de 21 de enero de 1994. En su párrafo 49 expresa, en lo pertinente: "La Corte ha sostenido que 'en los procesos sobre violaciones de derechos humanos, la defensa del Estado no puede descansar sobre la imposibilidad del demandante de allegar pruebas que, en muchos casos, no pueden obtenerse sin la cooperación del Estado' (Caso Velásquez Rodríguez, Sentencia de 29 de julio de 1988. Serie C No.4, párr.135; Caso Godinez Cruz, Sentencia de 20 de enero de 1989. Serie C No.5, párr.141)".

${ }^{247}$ Claras referencias en Medina Quiroga, C., cit. (n. 36), pp. 20, 27, 166, 185 , 188 y 221 . Reproducimos la parte que interesa de esta última: "Si la víctima alega la ilegalidad de la detención, corresponderá al Estado, acusado por un particular de haber infringido su propia ley, demostrar ante el órgano internacional que ello no ha ocurrido, acreditando que, a diferencia de lo que dice la presunta víctima, la persona que llevó a cabo el acto estaba autorizada por ley para hacerlo, o que los procedimientos rituales de la privación de libertad fueron seguidos. De no hacerlo así, se inferirá que la acción no fue legal". 
tema abierto: si es permitido acreditar la legalidad de la detención, ¿cabe vetar al imputado la posibilidad de proporcionar medios de prueba en contrario, en la audiencia? ${ }^{248}$

Hay casos en que al Estado no le es posible cumplir íntegramente con el régimen jurídico de la detención. Estimamos que plantear una excepción fundada en la imposibilidad de cumplimiento por su parte, es plausible. Sin embargo, tal alegación sólo debe ser admitida en tanto el incumplimiento no se deba a causas imputables a él mismo y, por otro lado, corresponderá siempre al propio Estado acreditar que existió el hecho generador de la imposibilidad $^{249}$.

\section{La conexión existente entre los derechos del articulo 7, números 5 y 6 , $C A D H$.}

El artículo 7.5 CADH, en su primera parte, establece el siguiente deber estatal: "Toda persona detenida o retenida debe ser llevada, sin demora, ante un juez u otro funcionario autorizado por la ley para ejercer funciones judiciales" ${ }^{250}$. La Constitución, a su vez, precisa que dicho funcionario sólo puede ser el juez competente ${ }^{251}$. Con ello se garantiza que la situación del

${ }^{248}$ Exponemos la situación dado que a veces el imputado tiene los medios para acreditar la ilegalidad. Por ejemplo, un joven es controlado en su identidad sin motivo y, al ser registrado, se le encuentra droga. Es detenido por delito flagrante y, tras él, parte un gran grupo de personas, que lo acompañaban. Asisten a la audiencia y están dispuestos a declarar cómo sucedieron los hechos. Cfr. Piedrabuena Richard, G., cit. (n. 102), p. 106. Estima que sólo debe declararse la ilegalidad "si la policía reconoce que el control de identidad lo efectuó sin ningún indicio previo".

${ }^{249}$ O’ Donnell, D., cit. (n. 101), pp. 319-320. Cita jurisprudencia del Comité de Derechos Humanos que desestima como argumento para el cumplimiento de las obligaciones estatales en la materia, el existir restricciones presupuestarias. Cfr. HoRvitz, M. I. - LópeZ, J., cit. (n. 62), I, p. 384. A propósito de la conducción inmediata del detenido a presencia del juez, refieren la necesidad de acreditar que los actos realizados tendían a ello, en caso que se supere el plazo legal. Cfr. Marín González, J. C., cit. (n. 76), p. 29. Se refiere a la incomparecencia del fiscal a la audiencia de control de la detención, por razones de fuerza mayor.

${ }^{250}$ La segunda parte de la disposición alude al derecho del privado de libertad a ser juzgado dentro de un plazo razonable o a ser liberado, pues su condición requiere reforzar lo ya estatuido a favor de todo imputado: la prohibición de dilaciones indebidas en su juzgamiento. Pero este derecho tendrá relación, más bien, con el control de la duración de la prisión preventiva. Véanse los artículos 8.1 CADH., 9.3 y 14.3 c) PIDCP. Cfr. Horvitz, M. I. - López, J., cit. (n. 62), I, p. 73. O’Donnell, D., cit. (n. 101), p. 324. Medina Quiroga, C., cit. (n. 36), pp. 233 ss.

${ }^{251}$ Artículo $19 \mathrm{~N}^{\circ} 7 \mathrm{c}$ ) C.Pol. Por esto, cabe destacar la redacción del actual artículo 70 inciso 2 CPP., incorporada por la Ley $\mathrm{N}^{\circ} 20.074$, que declara competente para el control de la detención por orden judicial no sólo al juez que ha dictado ésta, sino también al del lugar de la detención. 
imputado sea evaluada por un órgano independiente de los encargados de la persecución penal. Dado que el juez, para una labor acabada, requerirá constatar la existencia y estado de la persona, así como escuchar lo que ésta desee expresar, no cabe el ejercicio del derecho que fluye de la disposición mediante la sola comparecencia del defensor, constituyendo así una excepción al artículo $104 \mathrm{CPP} .{ }^{252}$. La finalidad de la conducción del detenido ante el juez competente, es que éste controle la legalidad de la detención ${ }^{253}$. En consecuencia, la disposición que se comenta está en íntima relación con la norma del artículo 7.6 CADH., ya que posibilita materialmente el ejercicio del derecho contenido en esta última ${ }^{254}$.

El artículo 7.6 CADH. establece: "Toda persona privada de libertad tiene derecho a recurrir ante un juez o tribunal competente, a fin de que éste decida, sin demora, sobre la legalidad de su arresto o detención y ordene su libertad si el arresto o la detención fueran ilegales" 255 . Como se trata de un derecho general del privado de libertad -no exclusivo del detenido, ni tan siquiera del imputado en el proceso penal-, la manera concreta de ejercerlo es variable. Desde luego, no puede tomarse el vocablo "recurrir" en un sentido técnico procesal, ya que esto limitaría su ámbito a las privaciones de libertad impuestas por resolución judicial.

Ahora bien, en el proceso penal, tratándose del detenido, junto con esta disposición deben tenerse en cuenta las prescripciones constitucionales y legales ${ }^{256}$. Todas ellas nos llevan a afirmar que, cada vez que un imputado es detenido, tiene derecho a ser llevado ante el juez competente ${ }^{257}$, para que éste controle la legalidad de la detención, en una audiencia efectuada especialmente (artículo 132 CPP.), sin perjuicio que pueda reclamarse la actividad jurisdiccional por otras vías (artículos 95 CPP. y 21 C.Pol.).

Aunque este trabajo no tiene por objeto referirse a los efectos de la declaración de ilegalidad de la detención, resulta oportuno aquí advertir que existe una contradicción entre el artículo 7.6 CADH., que dispone la orden de libertad del detenido ilegalmente, y el artículo 132 inciso $3^{\circ} \mathrm{CPP}$., que

${ }^{252}$ O’Donnell, D., cit. (n. 101), pp. 321-322.

${ }^{253}$ O’Donnell, D., cit. (n. 101), p. 323. Cita jurisprudencia de la Corte Interamericana de Derechos Humanos. Medina Quiroga, C., cit. (n. 36), p. 230.

${ }^{254}$ Bovino, A., cit. (n. 66), p. 81.

${ }^{255}$ Sobre el alcance que confiere la jurisprudencia internacional al "habeas corpus" y su vinculación con el artículo 25 CADH., Medina Quiroga, C., cit. (n. 36), pp. 252 ss.

${ }^{256}$ Arias Vicencio, C., cit. (n. 62), pp. 234-235. Plantea una visión de conjunto en la materia.

${ }^{257}$ Existiendo el deber estatal correlativo de ponerlo a su disposición, salvo cuando la ley autoriza dejar la detención sin efecto (artículo 131 inciso $2^{\circ} \mathrm{y}$, posiblemente, artículo 134 inciso $6^{\circ} \mathrm{CPP}$.). 
establece, en lo pertinente: "En todo caso, la declaración de ilegalidad de la detención no impedirá que el fiscal o el abogado asistente del fiscal pueda formalizar la investigación y solicitar las medidas cautelares que sean procedentes, de conformidad con lo dispuesto en el inciso anterior, pero no podrá solicitar la ampliación de la detención". Esta disposición busca que, no obstante se haya declarado la ilegalidad de una detención, el imputado permanezca en la audiencia, para así dar continuidad a la persecución penal, formulándose los cargos y, con ello poder solicitarse la prisión preventiva u otra medida cautelar (artículos 230 inciso $2^{\circ}$ y 140 CPP. $)^{258}$. Se aprecia que, dependiendo de la disposición que se emplee para ordenar los actos consecutivos de la audiencia, los resultados son diferentes. Para el artículo 7.6 CADH., tras la declaración de ilegalidad procede que el juez, acto seguido, disponga la puesta en libertad del imputado. En cambio, según el artículo 132 inciso $3^{\circ}$, a pesar de la declaración de ilegalidad, cabe mantener al imputado en la audiencia para los efectos señalados. A nuestro juicio, el conflicto se resuelve a favor del artículo 7.6 CADH., por las razones indicadas al exponer el problema de la jerarquía de las fuentes formales que regulan la detención, que resumidamente consisten en que lo dispuesto en un tratado internacional no puede ser dejado sin efecto por una ley, pues con ello se vulneraría la norma del artículo $54 \mathrm{~N}^{\circ} 1$ inciso $5^{\circ} \mathrm{C}$.Pol. y, si en la hipótesis se afectan derechos contenidos en un tratado de aquellos que señala el artículo 5 inciso $2^{\circ} \mathrm{C}$.Pol., además se infringiría ésta última disposición. Así, el artículo 132 inciso $3^{\circ}$ que, disimuladamente, establece la retención del imputado para continuar con la actividad procesal es, a nuestro parecer, inconstitucional.

\section{Conclusión}

Ya que a lo largo del presente trabajo se han presentado las opiniones que nos han merecido los diversos puntos examinados, sólo haremos un breve recuento de lo más importante.

El sistema de fuentes formales que rigen la detención es problemático, dada su dispersión. El intérprete se enfrenta a problemas al momento de establecer una jerarquía en la aplicación de las normas y al determinar los criterios para una interpretación coherente. Hemos intentado ofrecer una visión organizada que, encabezada por la Constitución Política, tome en cuenta todas las fuentes, en el orden que hemos considerado adecuado, con miras a la obtención de resultados prácticos. Deliberadamente hemos

${ }^{258}$ Cfr. Cisterna Pino, A., cit. (n. 101), pp. 64-65; Piedrabuena Richard, G., cit. (n. 102), pp. 124 ss.; Maturana Miluel, C. - Montero López, R., cit. (n. 78), pp. 468-470; Salas Astraín, Jaime, cit. (n. 101), pp. 369-372. 
prescindido de las teorías más optimistas en torno al sentido del artículo 5 inciso $2^{\circ}$ C.Pol., en materia de derechos fundamentales, pues ello habría diluido nuestra línea argumental, dada la ambigüedad interpretativa a que se presta su texto. Nos ha parecido relevante, sí, insistir en la obligatoriedad de la aplicación de las normas contenidas en los tratados internacionales mencionados, que a veces parecieran ser preteridas.

De paso, hemos manifestado nuestra opinión acerca de la posible inconstitucionalidad de algunas disposiciones legales, por las razones expuestas.

Se ha tratado la detención en general y, luego, como afectación del derecho a la libertad personal, señalándose los requisitos para considerarla legítima. Tras ello, se ha abordado la diferencia entre detención ilegal y arbitraria.

$\mathrm{Al}$ formularse un concepto de detención ilegal, se ha pretendido que éste sea aplicable al proceso penal. Sus elementos nos han permitido, luego, realizar una distinción entre dos categorías: la detención ilegal originaria y la derivada. El objetivo de este ejercicio ha sido plantear un esquema claro de las hipótesis de ilegalidad -no exhaustivo, porque ello podría ser imposible-, que facilite su reconocimiento, por una parte, y otorgue sustento a la detención ilegal derivada, por otra, ya que a primera vista ella podría estimarse artificiosa o sin base normativa.

Se ha concluido haciendo referencia al juicio sobre la legalidad de la detención. Esto, para formular nuestra opinión acerca de qué criterios generales podrían tomarse en cuenta al momento de determinar si una detención es ilegal. Hemos afirmado la necesidad del control a posteriori, pero ex - ante, ya que sólo así se puede dimensionar adecuadamente la corrección jurídica, en el actuar de quienes ejecutan la detención. Ello nos ha conducido a tratar la problemática del error, tanto de hecho como de derecho, en la materia.

Vinculado con lo anterior, se ha analizado el problema de la prueba de la legalidad o ilegalidad de la detención. Por las razones expuestas, hemos concluido que, a quien corresponde acreditar la corrección en su actuar es al Estado, y no al revés, que el imputado deba probar que ha sido sometido a una detención ilegal.

\section{BiBLIOGRAFÍA}

Aldunate Lizana, Eduardo, Derechos fundamentales (Santiago, LegalPublishing, 2008).

Aldunate Lizana, Eduardo, La posición de los tratados internacionales en el sistema de fuentes del ordenamiento jurídico chileno a la luz del derecho positivo, en Revista Ius et Praxis, 16 (2010) 2.

Arias Vicencio, Cristián, El control jurisdiccional de la detención, en Revista de Estudios de la Justicia, 6 (2005). 
Bermúdez Soto, Jorge, Derecho administrativo general (Santiago, LegalPublishing, 2010).

BINDER, Alberto, Introducción al derecho procesal penal (2a edición, Buenos Aires, Ad Hoc, 1999).

Cançado Trinidade, Antonio, El derecho internacional de los derechos humanos en el siglo XXI (2a edición, Santiago, Editorial Jurídica de Chile, 2006).

Carocca Pérez, Alex, Las garantías constitucionales en el nuevo proceso penal, en Carocca Pérez, Alex - Duce Julio, Mauricio - Riego Ramírez, Cristián Baytelman Aronowsky, Andrés - Vargas Vivanco, Juan Enrique (editores), Nuevo proceso penal (Santiago, Conosur, 2000).

CASTRo Jofré, Javier, Introducción al derecho procesal penal chileno (Santiago, Lexis Nexis, 2006).

Cea Egaña, José Luis, Derecho constitucional chileno (2a edición, Santiago, Ediciones Universidad Católica de Chile, 2008).

Cerda SAn MARtín, Rodrigo, Manual del sistema de justicia penal (2a edición, Librotecnia, Santiago, 2010), I.

Chahuán SARrás, Sabas, Manual del nuevo procedimiento penal ( $4^{a}$ edición, Santiago, LexisNexis, 2007).

Cisterna Pino, Adolfo, La detención por flagrancia en el nuevo proceso penal (Santiago, Librotecnia, 2004).

Cодомво CAmpвell, Juan, Aspectos constitucionales de la reforma procesal penal, en Revista de Derecho Procesal, 20 (2005).

CORDERO QUINZACARA, Eduardo, Los principios y reglas que estructuran el ordenamiento jurídico chileno, en Ius et Praxis, 15 (2009).

Duce Julio, Mauricio - Riego Ramírez, Cristián, Proceso Penal (Santiago, Editorial Jurídica de Chile, 2007).

DuRÁn FuICA, Rodrigo, Medidas cautelares personales en el proceso penal (2a edición, Santiago, Librotecnia, 2007).

Evans De la cuadra, Enrique, Los derechos constitucionales (3a edición, Editorial Jurídica de Chile, Santiago, 1999).

García Morillo, Joaquín, El derecho a la libertad personal (Tirant lo Blanch y Universidad de Valencia, Valencia, 1995).

Gimeno Sendra, Vicente - Moreno Catena, Víctor - Cortés Domínguez, Valentín, Derecho Procesal Penal (3 ${ }^{a}$ edición, Madrid, COLEX, 1999).

Gimeno Sendra, Vicente, Derecho Procesal Penal (2a edición, Madrid, COLEX, 2004).

GuZmán Brito, Alejandro, El Derecho privado constitucional en Chile (Valparaíso, Ediciones Universitarias de Valparaíso, 2001).

Horvitz, María Inés - LóPez, Julián, Derecho procesalpenal chileno (Santiago de Chile, Editorial Jurídica de Chile, 2002), I.

Llanos Mansilla, Hugo, Teoría y práctica del Derecho internacionalpúblico (Santiago, Editorial Jurídica de Chile, 2009-2007), I y II.

MaIer, Julio, Derecho procesal penal (Buenos Aires, Editores del Puerto, 1996-2011), I y III.

MARín González, Juan Carlos, Las medidas cautelares personales en el nuevo Código Procesal Penal chileno, en Revista de Estudios de la Justicia, 1 (2002).

Maturana Miquel, Cristián - Montero López, Raúl, Derechoprocesalpenal (Legal Publishing, Santiago, 2010), I. 
Maturana Miluel, Cristián (coordinador), Reforma procesalpenal. Génesis, historia sistematizada y concordancias (Santiago, Editorial Jurídica de Chile, 2003), I.

Medina Jara, Rodrigo - Morales Palacios, Luis - Dorn Garrido, Carlos. Manual de Derecho procesal penal (2a edición, Lexis Nexis, Santiago, 2007).

Medina Quiroga, Cecilia, La Convención americana: Teoría y Jurisprudencia (Santiago, Centro de Derechos Humanos. Facultad de Derecho Universidad de Chile, 2003).

Nogueira Alcalá, Humberto, Derechos fundamentales y garantías constitucionales (Santiago, Librotecnia, 2008), I y II.

Novoa Monreal, Eduardo, Curso de Derecho penal chileno (Santiago, Editorial Jurídica de Chile, 1960), I.

O'Donnell, Daniel, Derecho internacional de los derechos humanos (2a edición, Santiago, Editor Alejandro Valencia Villa, 2007).

Piedrabuena Richard, Guillermo, Ley No 20.253 Agenda corta antidelincuencia (Santiago, Legis, 2008).

Politoff Lifschitz, Sergio - Matus Acuña, Jean Pierre - Ramírez Guzmán, María Cecilia, Lecciones de derecho penal chileno. Parte General (Santiago, Editorial Jurídica de Chile, 2004).

Pujadas Tortosa, Virginia, Teoria general de las medidas cautelares penales (Marcial Pons, Madrid, 2008).

RABI GONZÁLEZ, Roberto, Roly justificación del control de identidad a la luz del actual texto del artículo 85 del Código Procesal Penal, en Revista de Derecho de la Universidad Católica de la Santísima Concepción, 18 (2008).

Risso Ferrand, Martín, Algunas garantías básicas de los derechos humanos (Montevideo, Fundación de Cultura Universitaria, 2008).

Roxin, Claus, Derecho procesal penal (Buenos Aires, Editores del Puerto, 2003).

Salas Astraín, Jaime, Problemas del proceso penal (Santiago, Librotecnia, 2009).

Silva Bascuñán, Alejandro, Tratado de Derecho constitucional (Santiago, Editorial Jurídica de Chile, 1997-2008), IV y XII.

Soto Simpson, María Cristina, La importancia de la fundamentación de la orden de detención escrita (Memoria para optar al grado de Licenciada en Ciencias Jurídicas, Pontificia Universidad Católica de Valparaíso, 2011).

Tavolari Oliveros, Raúl, Las medidas cautelares, en Revista de Derecho Procesal, 20 (2005).

Verdugo Marinkovic, Mario - Pfeffer Urquiaga, Emilio - Nogueira AlCALÁ, Humberto, Derecho constitucional (2a edición, Editorial Jurídica de Chile, Santiago, 2005), I.

Zalaquett Daher, José - Nash Rojas, Claudio, Proceso penal y derechos humanos, en Revista de Derecho Procesal, 20 (2005). 
